

\section{DISCLAIMER}

This report was prepared as an account of work sponsored by an agency of the United States Government. Neither the United States Government nor any agency Thereof, nor any of their employees, makes any warranty, express or implied, or assumes any legal liability or responsibility for the accuracy, completeness, or usefulness of any information, apparatus, product, or process disclosed, or represents that its use would not infringe privately owned rights. Reference herein to any specific commercial product, process, or service by trade name, trademark, manufacturer, or otherwise does not necessarily constitute or imply its endorsement, recommendation, or favoring by the United States Government or any agency thereof. The views and opinions of authors expressed herein do not necessarily state or reflect those of the United States Government or any agency thereof. 


\section{DISCLAIMER}

Portions of this document may be illegible in electronic image products. Images are produced from the best available original document. 
Printed in the United States of America. Available from National Technical Information Service. U.S. Department of Commerce 5285 Port Royal Road, Springfield, Virginia 22161 NTIS price codes-Printed Copy: A04; Microfiche A01

This report was prepared as an account of work sponsored by an agency of the United States Government. Neither the United States Government nor any agency thereof, nor any of their employees, makes any warranty, express or implied, or assumes any legal liability or responsibility for the accuracy, completeness, or usefulness of any information. apparatus, product, or process disclosed, or represents that its use would not infringe privately owned rights. Reference herein to any specific commercial product, process, or service by trade name, trademark, manufacturer, or otherwise, does not necessarily constitute or imply its endorsement, recommendation, or favoring by the United States Government or any agency thereot. I he views and opinions of authors expressed herein do not necessarily state or reflect those of the United States Government or any agency thereof. 
ORNL/TM-6250

Dist. Category UC $90 \mathrm{f}$

Contract No. W-7405-eng-26

Engineering Technology Division

SUMMARY OF THE RESEARCH AND DEVELOPMENT EFFORT

ON STEAM PLANTS FOR ELECTRIC-UTILITY SERVICE

A. P. Fraas

Prepared by the

OAK RIDGE NATIONAL LABORATORY

Oak Ridge, Tennessee 37830

operated by

UNION CARBIDE CORPORATION

for the

DEPARTMENT OF ENERGY 
THIS PAGE

\section{WAS INTENTIONALLY \\ LEFT BLANK}


NO Emissions . . . . . . . . . . . . . . . . . . . . . 44

Coal Metering and Feed Equipment . . . . . . . . . . 45

Fireside Corrosion ............... . . 4 46

Fast Fluldized Beds ................... 47

REFERENCES . . . . . . . . . . . . . . . . . . . 49 


\section{ACKNOWLEDGMENTS}

Among the many who helped provide material for this report, a special debt is owed M. L. Myers of ORNL, who supplied a wealth of material from his personal files. Others who were particularly helpful include E. L. Daman of Foster-Wheeler, R. T. King and G. Samuels of ORNL, together with D. M. Willyoung, J. L. Mangan, and W. B. Wilson of the General Electric Company. 


\title{
SUMMARY OF THE RESEARCH AND DEVELOPMENT EFFORT ON STEAM PLANTS FOR ELECTRIC UTILITY SERVICE
}

\author{
A. P. Fraas
}

\section{ABSTRACT}

The development of steam power plants for electric utility service over the past century is reviewed with particular emphasis on the prime problems and their solution. Increases in steam pressure and temperature made possible by developments in metallurgy led to an increase in thermal efficiency by a factor of 8 between 1880 and 1955. Further improvements have not been made because the use of still more expensive alloys is not economically justified, even with the much higher fuel prices of the latter 1970's. In fact, EPA regulations on waste heat and sulfur emissions have led to the use of cooling towers and wet limestone stack gas scrubbers that cause a degradation in plant thermal efficiency. The various possibilities for further improvements in efficiency and their problems are examined.

The development of steam power plants in the past has been carried out in sufficiently small steps that the utilities and the equipment manufacturers have been able to assume the financial risk involved; but the fluidized-bed combusion system, which appears to be the most promising area, presents such a large step with major uncertainties that U.S. government financial support of the research and development effort appears to be required. The potential benefits appear to justify the research and development cost many times over.

\section{INTRODUCTION}

This is one of a series of topical reports reviewing the research and development (R\&D) effort on one of a set of advanced energy conversion systems. ${ }^{2}$ The first portion of each report briefly summarizes the background by giving a chronological history of the research and development effort on the system up to 1976 along with the cumulative costs and system operating times. The next section points up the significant problem areas and recommends experiments deemed most likely to resolve these problems. This is followed by a more detalled discussion of the principal problem areas, performance parameters, and figures of merit characteristic of the system, together with the current status of the development 
work, with particular reference to progress in improving the principal performance parameters.

This report represents a special case in that it is concerned with the well-established steam system on which our whole economy is based. It serves as the basic reference system against which the others can be compared.

This work was carried out at the request of the Office of Program Planning and Analysis of the DOE Fossil Energy Program using funds provided for a general appraisal of advanced fossil energy systems.

\section{BACKGROUND}

The development of steam plants for utility service in the U.S. began with the construction ${ }^{2}$ of the Brush Electric Light Company plant in Philadelphia in 1881. Construction of other plants followed rapidly throughout the country to satisfy the need for electric power for lighting and for electric street railways. ${ }^{3,4}$ Initially, single expansion reciprocating steam engines were employed. By 1890, double-expansion engines and shortly thereafter triple-expansion engines became common, leading to increases in steam pressure and temperature. By 1900, the advantages of a steam turbine in permitting a still greater expansion ratio became apparent, and in 1904 the first steam turbine in U.S. utility service went into operation giving a higher thermal efficiency than any reciprocating engine in service. ${ }^{3-8}$ Whereas overall expansion ratios of more than 100 were not practicable in reciprocating engines and hence there was no incentive from the standpoint of thermal efficiency to go to steam pressures in excess of about 10 bars (150 psi), a steam turbine could employ much higher expansion ratios to good advantage, thus leading to fairly rapid increases in both temperature and superheat. Note also that lubrication considerations in reciprocating steam engines limited the peak permissible steam temperature to around $180^{\circ} \mathrm{C}\left(350^{\circ} \mathrm{F}\right)$, but this limitation did not apply to steam turbines.

The rapidly increasing size of power plants led to the development of traveling grate and other types of mechanical stoker, and these rapidly displaced hand-fired boilers. ${ }^{3}$ Improvements in metallurgy made possible 
higher strength steels with greater resistance to corrosion, thus leading to further increases in pressure and temperature throughout the $1920^{\prime} \mathrm{s}$ together with concurrent increases in unit size. ${ }^{4}$ At the same time, refinements in the thermodynamic cycle were made to improve the thermal efficiency by reheating, ${ }^{9}$ regenerative feed heating, and air preheating. Improved methods of feedwater treatment eased the corrosion problems on the steam side and reduced maintenance. ${ }^{2}$

By 1930 , developments in both electric welding techniques and $x$-ray inspection of welds made it possible to go from riveted header drums with rolled tube-to-header joints to welded header drums, tube-to-header joints, and plant piping. ${ }^{2}$ This in turn permitted marked further increases in the system temperature and pressure to around 170 bars (2450 psi) and $565^{\circ} \mathrm{C}\left(1050^{\circ} \mathrm{F}\right)$, so that by 1950 central station steam plants had virtually reached the operating conditions current at the time of writing.10,11 Concurrently, the reliability of boilers and turbines increased sufficiently that the initial practice of manifolding a multiplicity of boilers to a multiplicity of turbines was dropped in favor of independent units with each boiler coupled to a particular turbine. This simplified the piping (particularly provisions for thermal expansion) and eliminated many large shutoff valves which gave a great deal of trouble when used at high temperatures and pressures. In the 1950's, the oncethrough boiler came into use and was almost immediately applied to produce supercritical pressure steam, commonly 240 bars $(3500 \mathrm{psi})$ and $565^{\circ} \mathrm{C}$ $\left(1050^{\circ} \mathrm{F}\right) \cdot{ }^{12^{-16}}$ A flowsheet for a typical modern plant ${ }^{17}$ is shown in Fig. 1 .

The highlights ${ }^{18}$ of this long developmental history are summarized in Table 1 and Fig. 2. Note the steady increases in pressure and temperature up to 1957 , with a concomitant increase in thermal efficiency but with no further significant increases in any of these three parameters in the subsequent 20 years. Subsequent efforts up to the early 1970 's were directed primarily toward increases in both reliability and in unit size; the latter effect is also shown in Fig. 2.18 However, the reliability and availability ${ }^{19}$ of units have declined with increasing size, as indicated in Fig. 3. This stems in part from the increase in the number of boller tubes; for a given probabilily of a tube failure, 
ORNL-DWG 78-2063

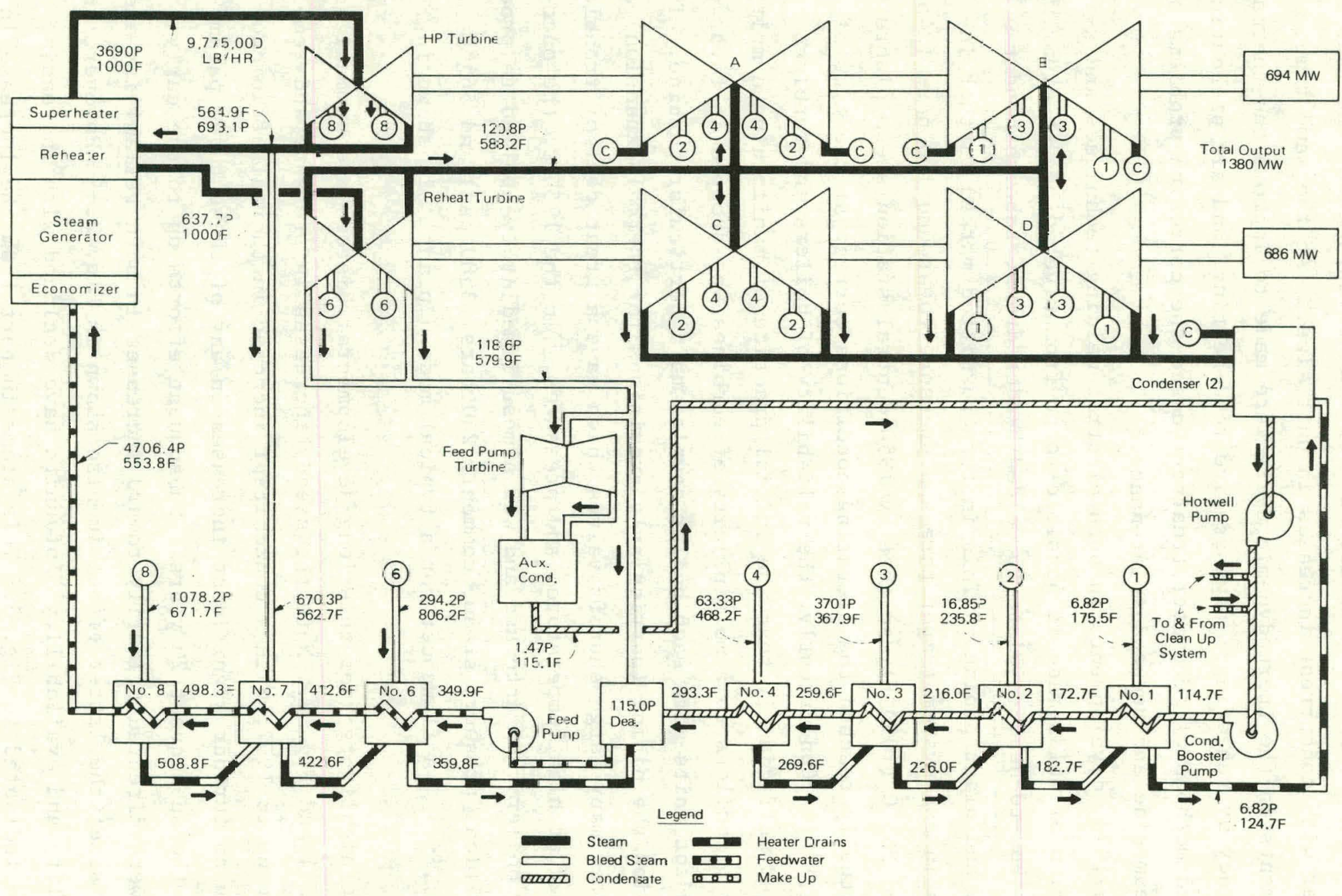

Fig. 1. Conventional utility steam cycle. 
Table 1. Principal developments in steam power plants for utility service

\begin{tabular}{|c|c|c|c|c|c|}
\hline \multirow[b]{2}{*}{ Period } & \multicolumn{4}{|c|}{ Typical parameters for new plants } & \multirow[b]{2}{*}{ Principal developments } \\
\hline & $\begin{array}{l}\text { Peak } \\
\text { temp. } \\
{\left[{ }^{\circ} \mathrm{C}\right.} \\
\left.\left({ }^{\circ} \mathrm{F}\right)\right]\end{array}$ & $\begin{array}{l}\text { Peak } \\
\text { press. } \\
\text { [bars } \\
\text { (psia)] }\end{array}$ & $\begin{array}{l}\text { linit } \\
\text { output } \\
\text { (NW) }\end{array}$ & $\begin{array}{l}\text { Full. load } \\
\text { thermal } \\
\text { effic. } \\
\quad(\%)\end{array}$ & \\
\hline $1880-1890$ & $\begin{array}{l}173 \\
(344)\end{array}$ & $\begin{array}{c}8.6 \\
(12.5)\end{array}$ & 0.3 & 5 & $\begin{array}{l}\text { Generators belt-driven from reciprocating steam engines with hand-fired } \\
\text { boilers }\end{array}$ \\
\hline $1890-1900$ & $\begin{array}{l}173 \\
(344)\end{array}$ & $\begin{array}{l}9.0 \\
(130)\end{array}$ & 0.7 & 7 & $\begin{array}{l}\text { Double- and triple-expansion engines with Corliss poppet valve gear } \\
\text { introduced }\end{array}$ \\
\hline $1900-1910$ & $\begin{array}{l}181 \\
(358 ;\end{array}$ & $\begin{array}{c}10 \\
(145)\end{array}$ & 1 & 10 & $\begin{array}{l}\text { Steam turbine with steam superheat came into common use with mechanical coal } \\
\text { stokers }\end{array}$ \\
\hline $1910-1920$ & $\begin{array}{l}293 \\
(560:\end{array}$ & $\begin{array}{c}19 \\
(275)\end{array}$ & 10 & 15 & $\begin{array}{l}\text { Steam pressures and temperatures increased somewhat and sizes and efficiency } \\
\text { of turbines much increased }\end{array}$ \\
\hline $1720-1930$ & $\begin{array}{l}385 \\
(725 !\end{array}$ & $\begin{array}{c}38 \\
(550)\end{array}$ & 25 & 25 & $\begin{array}{l}\text { Large pulverized coal-fired boilers introdiced with new furnace designs } \\
\text { employing water-cooled walls with steam reheat, regenerative feed water } \\
\text { heating, and combustion air preheat; turbine sizes increased to as much as } \\
100 \mathrm{MW} \text {; feed water treated }\end{array}$ \\
\hline $1930-1940$ & $\begin{array}{l}482 \\
(900)\end{array}$ & $\begin{array}{c}62 \\
(900)\end{array}$ & 50 & 32 & $\begin{array}{l}\text { Arc-welded construction and new alloys permitted marked increase in pressure } \\
\text { and temperatures: large steam generators and turbines combined into single } \\
\text { units (to eliminate troublesome valves) replaced former multiplicity of } \\
\text { small boilers (as many as } 60 \text { in one Fowerhouse) manifolded to a multiplicity } \\
\text { of turbines; control of feed water chemistry improved }\end{array}$ \\
\hline $1940-1950$ & $\begin{array}{l}538 \\
(1000)\end{array}$ & $\begin{array}{c}83 \\
(1200)\end{array}$ & 150 & 36 & $\begin{array}{l}\text { Higher pressures and temperatures came into use with further improvements in } \\
\text { alloys and control of feed water chemistry; further increases in unit size }\end{array}$ \\
\hline $1950-1960$ & $\begin{array}{l}566 \\
(10510)\end{array}$ & $\begin{array}{l}165 \\
(3500)\end{array}$ & 300 & 38 & $\begin{array}{l}\text { Once-through and supercritical steam pressure systems came into use; turbine } \\
\text { designs improved to tolerate and remove much more moisture, thus permitting } \\
\text { use of saturated steam from nuclear plants; unit sizes increased further } \\
\text { and still better control of feed water chemistry was obtained }\end{array}$ \\
\hline $1960-1970$ & $\begin{array}{l}566 \\
(105 j)\end{array}$ & $\begin{array}{l}240 \\
(3500)\end{array}$ & 500 & 39 & Unit size further increased \\
\hline $1970-1980$ & $\begin{array}{l}538 \\
(1000)\end{array}$ & $\begin{array}{l}240 \\
(3500)\end{array}$ & 1000 & 36 & $\begin{array}{l}\text { EPA requirements led to widespread introduction of cooling towers, stack gas } \\
\text { scrubbers, and improved particulate removal equipment, all causing losses } \\
\text { in plant efficiency; further increases in unit size }\end{array}$ \\
\hline
\end{tabular}




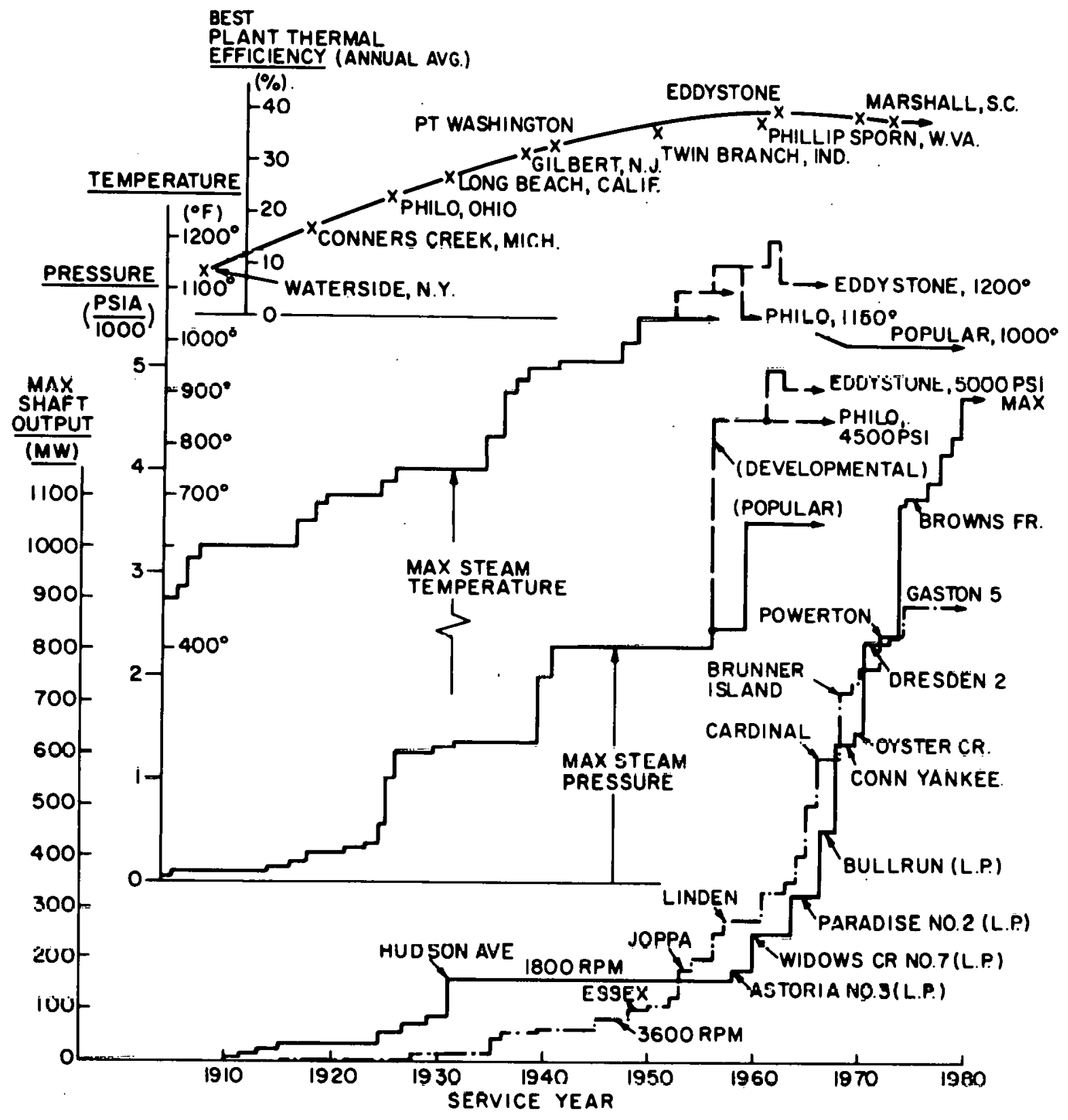

Fig. 2. H1storical development of advanced turbine-generators. ${ }^{18}$ 

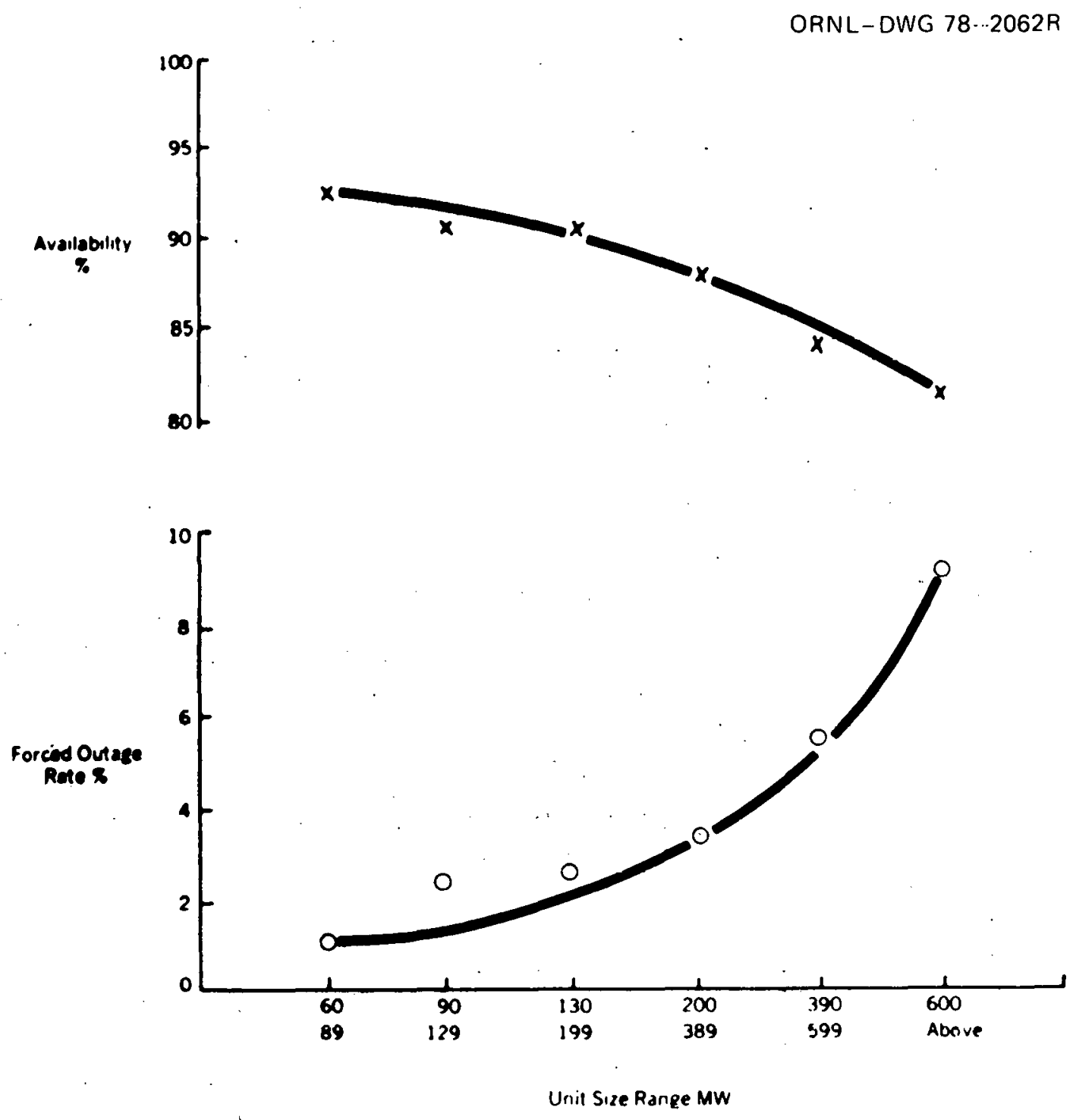

Fig. 3. Averages for 1965-1974 EEI availability data for fossil fuel steam turbine units as a function of unit size.

the probability of a forced outage from a boiler tube failure increases with unit size so that boiler tube failures become a larger fraction of the total outages. As a consequence, the trend toward even larger units seems to have been reversed in recent years (see Fig. 4).19

Since passage of the Environmental Protection Act of 1968, the prime emphasis has been on the reduction of stack gas emissions and the effects of waste heat rejection; both efforts have led to reductions in thermal efficiency. 


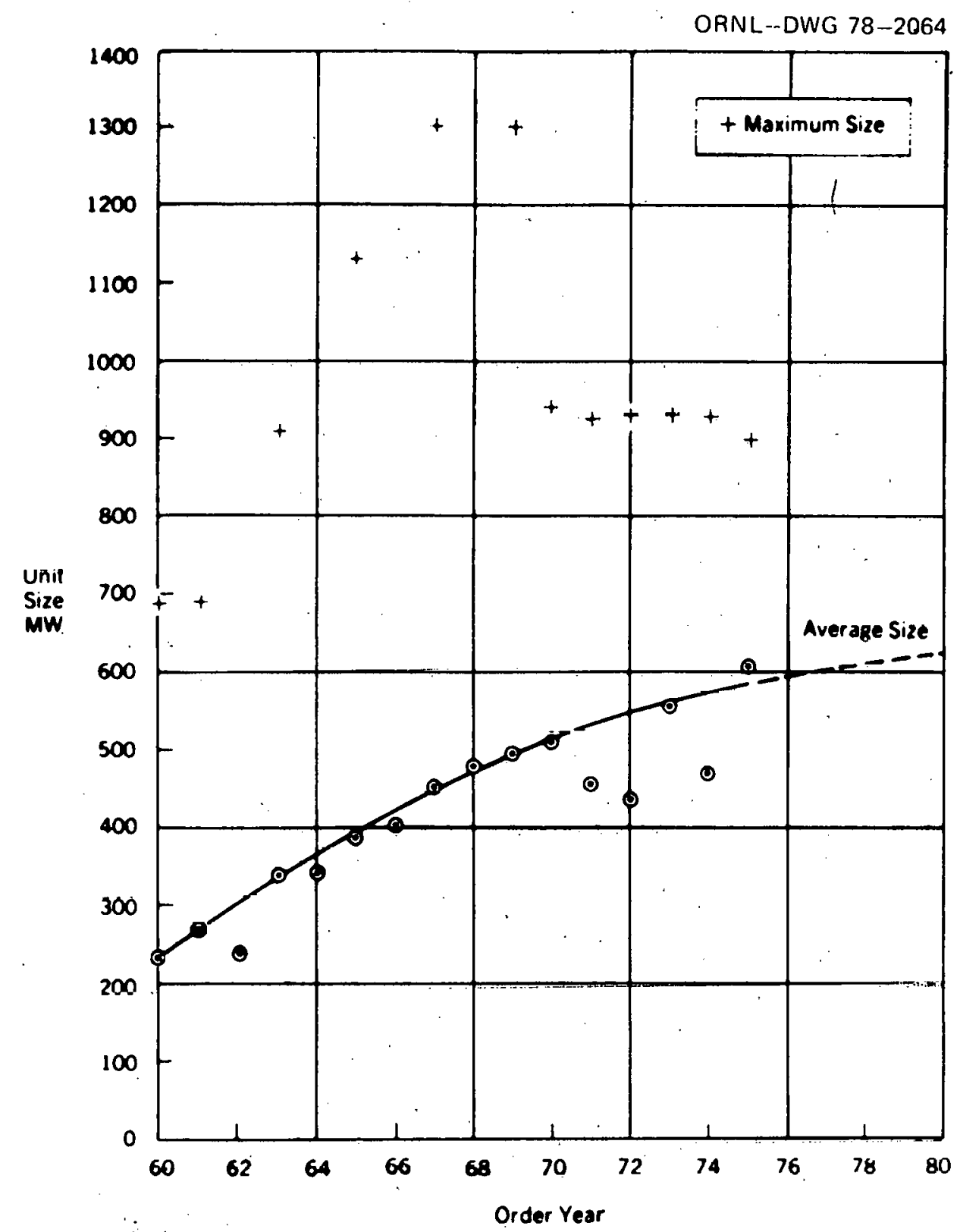

Fig. 4. Average and maximum size of fossil fuel steam turbine units as a function of the year in which they were ordered. 19

\section{Current Development Effort}

The principal concern in the 1970's. involved a reduction of emissions from central stations. This work included marked improvements in electrostatic precipitators to remove particulates, bag houses for even better 
removal of particulates, stack gas scrubbers to remove $\mathrm{SO}_{2}$, and improvements in furnace and burner design to reduce the emission of oxides of nitrogen. ${ }^{2-22}$ Most of this work has been carried out by superimposing new equipment on existing power plants. In addition, work has been under way to remove sulfur from the fuel before it is fed to the burners, by beneficiation, by solvent extraction of sulfur from coal, or by a coal gasification or liquefaction process that includes removal of the sulfur. 23,24

Several smal1-scale efforts to develop fluidized-bed coal combustion systems have been under way since the middle 1950's.25,26 This process has the advantage that if the coal is burned in a fluidized bed of 1imestone or dolomite, the bulk of the sulfur can be reacted with the lime to form calcium sulfate, thus drastically reducing sulfur emissions and avoiding the wet stack gas scrubbers and their attendant maintenance problems (which commonly add 230 men to the plant operating crew). A pilot plant designed to produce $30 \mathrm{MW}(\mathrm{e})$ has been built at Rivesville, West Virginia, and is undergoing shakedown tests at the time of writing. 27

A series of both generalized and specific design studies of fluidizedbed coal combustion systems for utility, as well as industrial and institutional applications, have been carried out to show the potential of fluidized-bed furnaces coupled to steam boilers. ${ }^{15,28-36}$ These studies indicate that the atmospheric-pressure fluidized-bed coal combustion. system gives a modest improvement in both thermal efficiency and costs compared with conventional pulverized coal-fired furnaces with stack gas scrubbers. 16, 28-36 Pressurizing the furnace to 10 aț for a gas turbinesteam cycle gives a marked reduction in furnace capital costs and some increase in thermal efficiency, but it presents gas turbine erosion and deposit problems so formidable that an economically attractive solution is doubtful for gas turbine inlet temperatures above $\sim 600^{\circ} \mathrm{C}\left(1110^{\circ} \mathrm{F}\right) .37,38$ However, the same body of experience indicates that erosion and deposit problems would be tolerable if the gas turbine inlet temperature were kept at $540^{\circ} \mathrm{C}\left(1000^{\circ} \mathrm{F}\right)$ or less. ${ }^{33}$ This would give sufficient turbine output to drive the compressor to supercharge the furnace to 3 to $6 \mathrm{~atm} .{ }^{33}$ A.lthough the turbosupercharger would not yield any elestrical output, it 
would greatly reduce the slze and capital cost of the furnace and give a thermal efficlency intermediate between that for the 1-atm bed-steam cycle and that for the 10-atm bed combined cycle. 33 Note that over 100 Velox bollers have been bullt by Brown Boveri for ofl firlng, clearly demonstrating the commercial practicality of turbosupercharged furnaces for steam plants operating with clean fuels.

\section{Cost of Developmental Efforts}

The bulk of the developmental effort on central station steam plants hao bcen in the [urm of a series of small incremental improvemente.17 Gradual improvements have been made in the steel alloys for steam generacors and turbines and have led to gradual increases in steam temperatures and pressures. ${ }^{39}$ Even major steps, such as the introduction of turbines, the use of reheat, the introduction of traveling grate stokers and later of pulverized-coal burners, and once-through and supercritical pressure boilers, have involved modest risks that could be assumed jointly by the electric utility and the equipment manufacturer.

A subtle but important role in the development of steam systems has stemmed from development work carried out for naval vessels. Parsons' initial work on steam turbines, for example, wao centered for à lime un the development of a moror torpedo boat. Incidentally, the boat achieved a speed of 32 knots in 1904, a fantastic achievement at the time. The U.S. Navy strongly supported developments for increased pressures and temperatures as a means of reducing the size and weight of both boilers and Luxbinco.

Efforto to estimate the cust of these developmental efforts have yielded too nebulous a set of numbers to be meaningfu1. Clearly, an enormous amount of money has been spent. For example, outages associated with the shakedown of a new piece of equipment in a power plant may run as much as $\$ 750,000$ per day because of overhead charges, 18 and there have been numerous instances in which. shakedown difficultics with new equipment have resulted in outages of as much as a year. The cost of each of these to the utility involved has been high. However, once such a plant 
is shaken down, the reduced fuel consumption because of the higher efficiency or the reduced operating costs because of increases in unit size have often repaid the shakedown cost in only a few years. Thus, the real secret of the successful financing of the development of steam plants by equipment manufacturers and private utilities has been that the incremental improvement in any given case has been relatively small and the risk involved has been within the financial capacity of the companies involved. Still, one must admire the men who have had the courage to stake their professional reputations on new developments that involved substantial risks.

The most promising concept currently under development for steam plants is the fluidized-bed coal combustion system. This shows promise of increasing the plant thermal efficiency, reducing capital costs, and reducing solid waste rejection. However, the limited experience with fluidized-bed coal combustion systems for steam generators is insufficient to provide a sound basis for the design of a large plant. Many small experimental units have been run, some very successfully, and one unit for a 30-MW(e) plant is undergoing shakedown tests at the time of

writing. ${ }^{28}$ However, experience with the petroleum catalyt1c cracking units and other fluidized beds employed in chemical processing indicates that scale effects can be pronounced. For example, the limited data on fireside corrosion shows wide variations in fireside corrosion rates from one test to another. Thus, much further work on the basic technology of fluidized-bed combustion systems is needed.

The total cost of the U.S. effort on fluidized-bed coal combustion systems up to the time of writing has been about $\$ 50,000,000$ and the total running t1me on the units in U.S. programs (including work in England funded by the U.S.) has been $\sim 20,000 \mathrm{hr}$.

\section{RE.COMMENDATIONS}

The operating experience with fluidized-bed coal combustion systems for steam generators indicates that the basic technology required for the design of these systems is not well in hand, and a great deal of work is urgently needed. If this work is to be carried n!tt and the 
results disseminated expeditiously to those who can use them to advantage, much of the work will require Government funding. The principal areas requiring attention are as follows:

1. Effects on fireside corrosion of choice of alloy or coating, bed temperature, metal temperature, type of coal, type of limestone, average fuel-air ratio, air velocity through the bed, particle sizes of coal and limestone, furnace pressure, coal sulfur content, and the calcium-sulfur ratio. Other even more subtle factors such as furnace deslgn will also be important.

2. Long-livel cual feed and merering equipment is required to maintain a closely controlled fuel feed rate. This work must be closely related to methods of coal preparation and the specification of permissible moisture content.

3. The spacing of coal feed ports and their position in a fluidized bed influences the extent to which there may be local variations in fuelair ratio and hence the possibility of local fluctuations between oxidizing and reducing conditions (which would have a major effect on the fireside corrosion rates). The greater the spacing, the fewer the number of coal feed points and the less expensive the coal feed and metering system but the greater the tendency for local. variations in the fuelair ratio. This problem will require extensive testing in fluidized-bed coal combustion systems having cross-sectional areas of at least $4 \mathrm{~m}^{2}$ and possibly as much as $10 \mathrm{~m}^{2}$.

4. Reduction in capital costs for the fluidized-bed furnace can be effected if the furnace pressure is increased. 16,29,33 This can be best accomplished if the compressor employed to pressurize the furnace is driven by a gas turbine utilizing the products of combustion. However, extensive experience with gas turbines operated on the products of combustion of coal indicates that turbine bucket erosion and deposits severely limit the life of the turbine, and the problems become progressively more serious as the turbine inlet temperatures increase. Particulate removal equipment currently available will permit turbine inlet temperatures as high as $600^{\circ} \mathrm{C}\left(1110^{\circ} \mathrm{F}\right) .37,38$ Further tests are needed to 
determine whether this limit is in fact acceptable and would permit operation. of a free turbine-driven supercharger to maintain a furnace pressure of 3 to $5 \mathrm{~atm}$ (which appears to give a very useful and economically attractive system) or whether higher turbine inlet temperatures can be obtained, in which case the gas turbine might also produce some useful power.

\section{PRINCIPAL PROBLEMS AND PARAMETERS}

The principal items discussed in this section fall into one of three categories: metallurgical developments, design parameters affecting thermal efficiency and costs, and fluidized-bed coal combustion systems. Metallurgical developments are presented first because this effort has largely paced the rest of the work. The design parameters affecting efficiency and cost are treated next, while the special problems of fluidized-bed coal combustion systems (the principal area seen for future development) are treated in the last part of this section.

\section{Metallurgical Developments}

Tremendous developments in the strength and corrosion resistance of steel alloys took place in the period from 1910 to $1950 .{ }^{39}$ Much of this work was done by the steel companies, and major contributions were also made by the boiler and turbine manufacturers. Some of this, of course, entailed the development of various alloys, but important elements included improvements in melting and fabrication practice.

\section{Welding}

Perhaps the most significant single development was the improvement in shielded-arc electric welding techniques to yield sound welds in header drums, and the validation of the soundness of the welds by x-ray techniques to the point where this procedure was accepted by both the U.S. Navy and the ASME Pressure Vessel Code by $1930 .{ }^{2}$ The riveted construction previously employed was not only clumsy and more expensive, but it also limited the thickness of the plate used. in fabricating header drums 
to about $5 \mathrm{~cm}$ (2 in.) and thus limited both the size and the pressure that could be used readily in a steam boiler. Welding was soon applied not only to header drums, but also to tube-to-header joints and to the fabrication and installation of plant piping so that flanged joints in high-temperature, high-pressure steam systems quickly became a thing of the past. This cut both initial capital costs and maintenance costs.

\section{Creep strength of alloys}

Creep strength considerations become important in low-alloy steels for temperatures above $430^{\circ} \mathrm{C}\left(806^{\circ} \mathrm{F}\right)$ and become completely dominant for all $\mathrm{Fe}-\mathrm{Cr}-\mathrm{Ni}$ alloys above $540^{\circ} \mathrm{C}\left(1004^{\circ} \mathrm{F}\right)$. The importance of the effect is shown in Fig. 5, which shows the ASME allowable stresses for several representative alloys employed in steam power plants as a function of temperature.

In choosing an allowable stress for a particular component in the design of a steam generator, one must consider not only the temperature

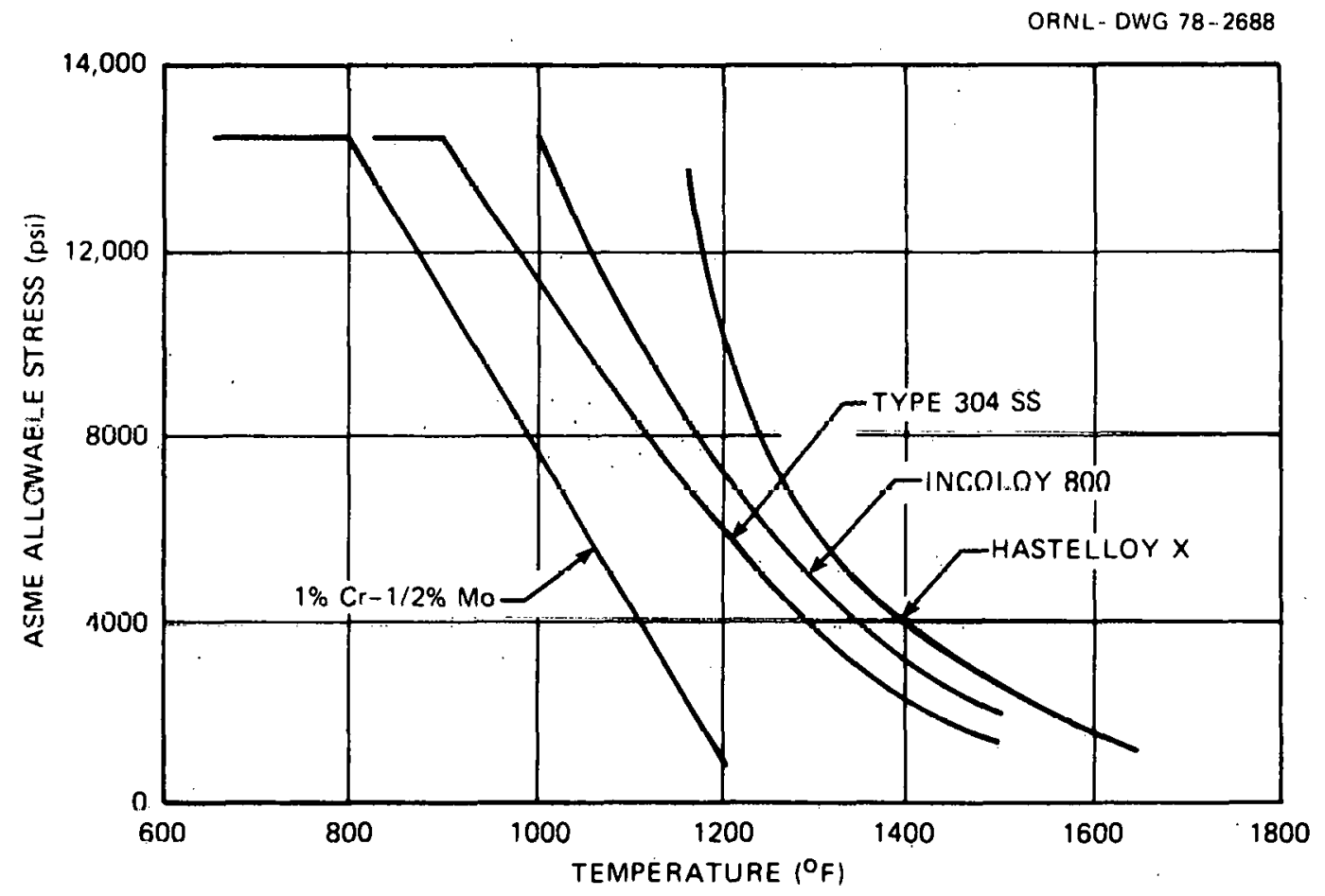

Fig. 5. Effects of design temperature on the ASME Pressure Vessel Code allowable stress for four typical alloys. 
difference between a heated tube wall and the steam flowing past it, but also hot-spot effects stemming from deviations from ideality in the temperature and velocity of the hot gases flowing over a tube bank together with deviations from ideality in the steam flow distribution through the tube bank. Thus, the allowable stress must be based on the peak metal temperature to be expected in a perverse tube in which the steam velocity would be lower than the average, the steam temperature would be higher than the average, and the external hot gas velocity and temperature would both be higher than the average. Thus, in choosing an allowable stress for a superheater tube designed to produce $565^{\circ} \mathrm{C}\left(1050^{\circ} \mathrm{F}\right)$ steam, one must allow for a temperature drop from the tube wall to the steam of around $50^{\circ} \mathrm{C}$, a temperature drop through the tube wall of perhaps $25^{\circ} \mathrm{C}$ for an average tube, and about double these values for a perverse hot tube. As a consequence, steam generator designers commonly take a value of perhaps $650^{\circ} \mathrm{C}\left(1200^{\circ} \mathrm{F}\right)$ as indicative of the highest local metal temperature in the superheater tube matrix. It is evident from Fig. 5 that this greatly reduces the allowable stress from the value one might first expect to be applicable [i.e., that for the steam outlet condition of $565^{\circ} \mathrm{C}\left(1050^{\circ} \mathrm{F}\right)$ ]

Superheater tubes are commonly made of 5-cm-OD (2-in.) tubes. For a steam pressure of 240 bars ( 3500 psi), Fig. 6 shows the tube wall thickness as a function of tube wall temperature for the alloys of Fig. 5 . In practice, it has been found impractical to use a tube wall thickness greater than the inside radius of the passage.

In attempting to increase the strength of the steel alloy by using progressively greater amounts of expensive alloy materials, one flinds that the cost of the material increases rapidly. Further, the higher alloy materials are more difficult to fabricate. In practice, it has been found that the austenitic stainless steels containing about $18 \%$ chromium and $8 \%$ nickel are about as expensive as can be justified.16,29,40 An indication of this effect on costs is given by Fig. 7.

Fireside corrosion

Fireside corrosion is a major factor limiting the peak temperature of steam generators. ${ }^{40-42}$ The oxidation resistance of steels is markedly 


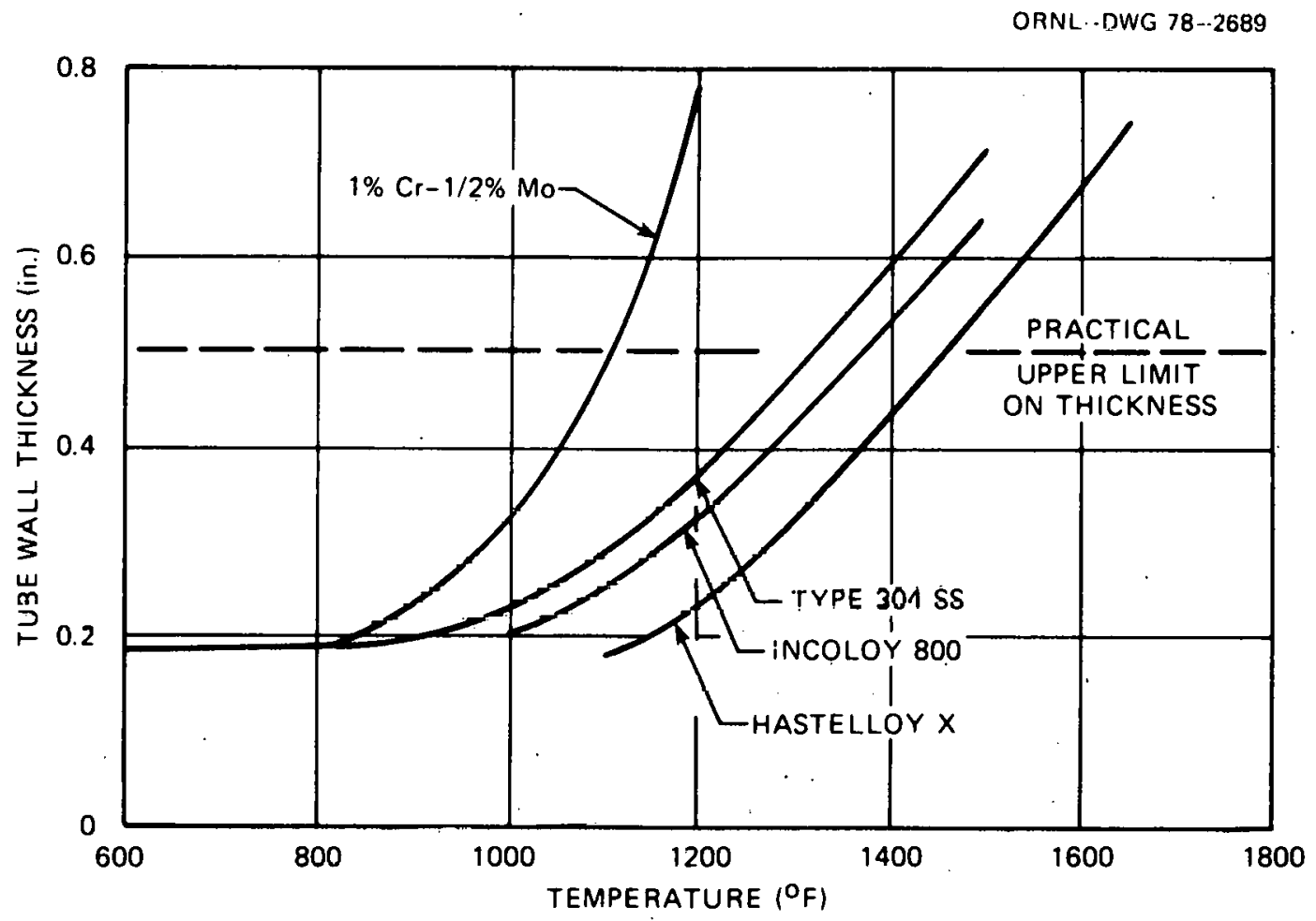

F1g. 6. Effects of design temperature on the wall thickness of 5 -cm-OD (2-in.) tubing of four typical alloys for operation at 240 bars (3500 psi).

Increased by the addition of chromium because a protective layer of chromium oxide forms under oxidizing conditions. Note that it is essential that the atmosphere around the metal not fluctuate from oxidizing to reducing conditions because this leads to very rapid oxidation attack. Substantial aniunts of chromium in a steel tend to make it brittle, but this can be corrected by the addition of nickel - hence the use of the $18 \% \mathrm{Cr}-8 \% \mathrm{Ni}$ stainless steels.

Fireside corrosion presentc an exiesdingly complex set of problems. For the relatively high chromium-nickel alloys such as the $18 \% \mathrm{Cr}-8 \% \mathrm{Ni}$ stainless steels, the attack by oxidation takes place very slowly even at temperatures of $870^{\circ} \mathrm{C}\left(1600^{\circ} \mathrm{F}\right)$ if the fuel is a pure hydrocarbon and there is also a small excess of oxygen. If the amount of sulfur in the fuel exceeds about $0.3 \%$, corrosion proceeds much more rapidly. If, in addition to the sulfur, there are the alkali metals sodium and potassium 
ORNL-DWG 78-2690

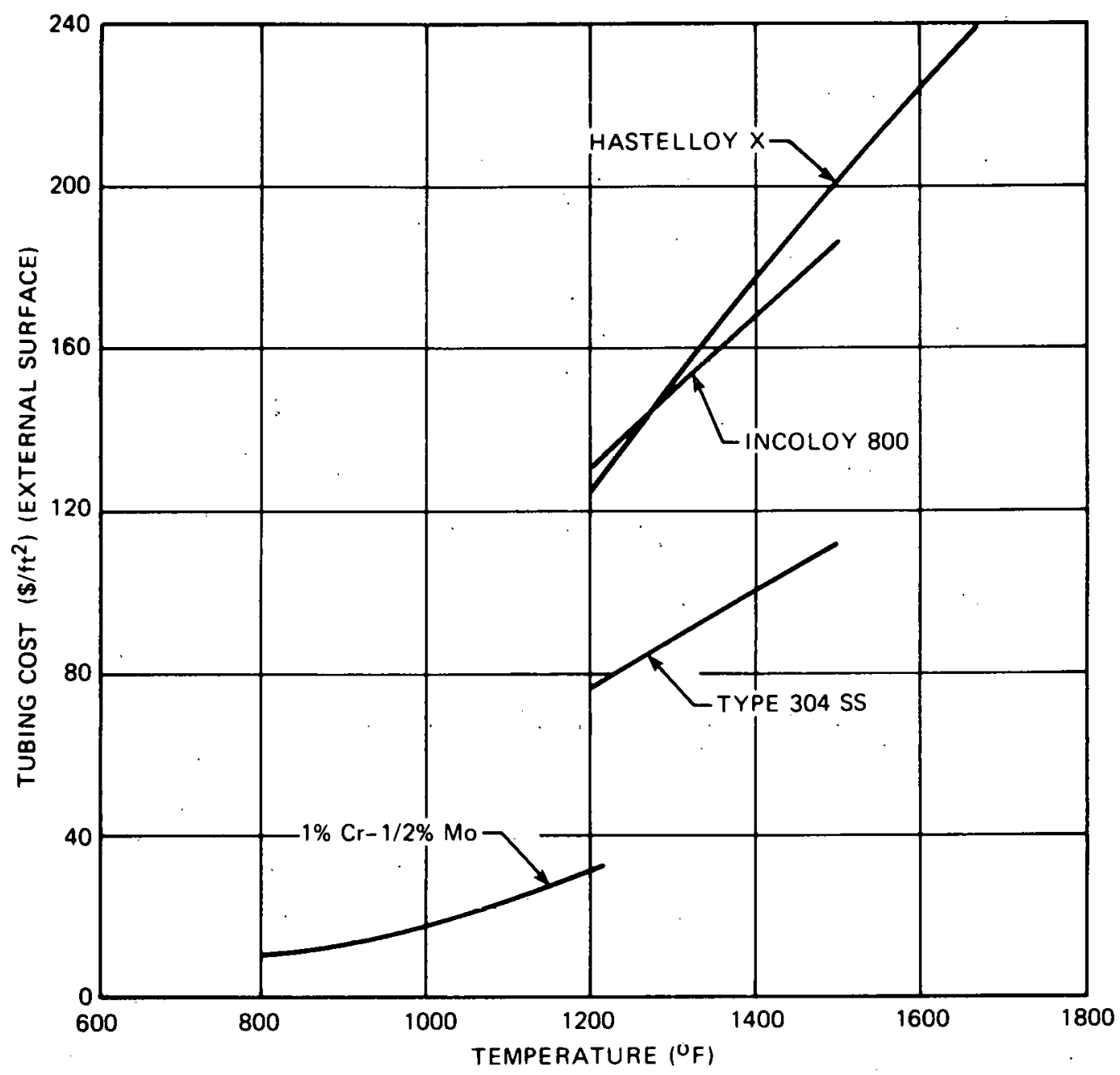

F1g. 7. Effects of design temperature (and hence tube wall thickness) on the cost of $5-\mathrm{cm}-O D(2-i n$.$) tubing of four typical alloys for$ service at 240 bars ( 3500 psi).

and also vanadium and/or chlorine, attack can proceed very rapidly indeed. 41 This apparently stems from the fact the liquid alkali metal sulfates and vanadates vaporized in the flame will condense out on metal surfaces in the 650 to $732^{\circ} \mathrm{C}\left(1200\right.$ to $\left.1350^{\circ} \mathrm{F}\right)$ range, resulting in a highly corrosive liquid $\mathrm{film}^{42}$ (see Fig. 8). The problem is too complex to treat here other than to indicate its magnitude and complexity by pointing to Fig. 9 and Tables 2 and 3 . These data are from a set of tests in which racks of specimens were suspended in the superheater 
ORNL ‥DWG 78- 2691

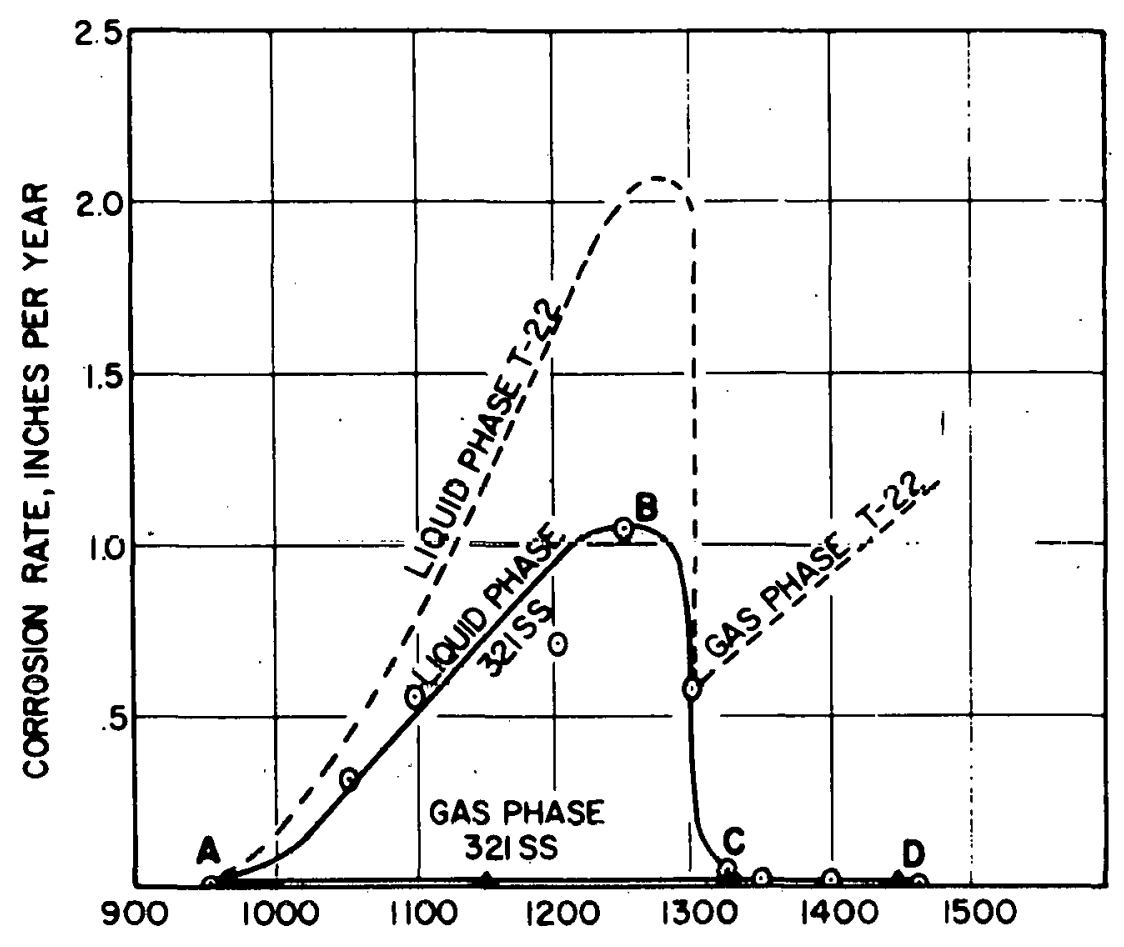

TEMPERATURE, ${ }^{\circ} \mathrm{F}$

Fig: 8. Comparioon of liquid- and gas-phase corrosion rates on 321 stainless steel..$^{4}$

region of each of a set of power plants chosen to give a wide range of fuel conditions. ${ }^{43}$ In each case the rack of specimens was placed in a region such that the local gas temperature was $732^{\circ} \mathrm{C}\left(1350^{\circ} \mathrm{F}\right)$. The original intent was to expose the specimens for 6 months, but the corrosion rate was monitored in the two stations known to have the most severe corrosion conditions. The specimens in these stations were checked at the end of 3 months and found to be so severely attacked that further testing was inadvisable. It was then decided to terminate the tests of the other sets as well. As a consequence, the exposure time varied from 90 to 160 days; the shorter periods of exposure were for the stations with the most severe corrosion conditions and the longer periods for those with the least severe conditions. Inspection of these data shows clearly that the corrosion rate of most of the materials with clean fuel was quite acceptable, whereas 


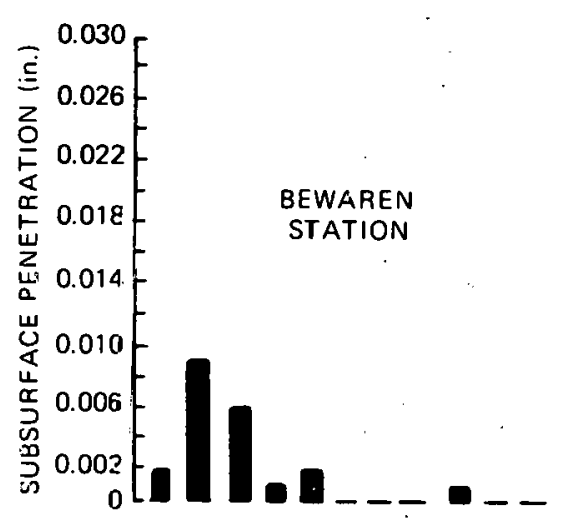

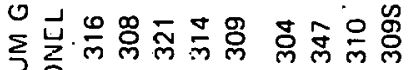

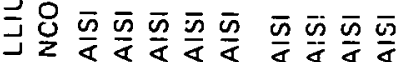

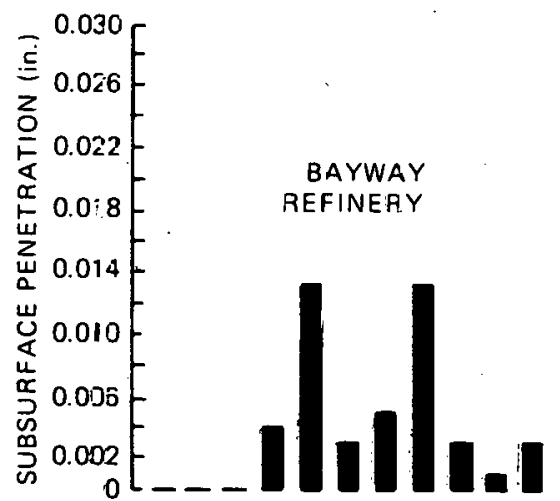

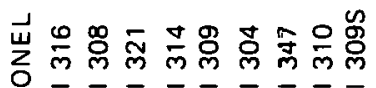

导 $\frac{\bar{n}}{\alpha} \frac{\bar{n}}{\bar{\alpha}} \frac{\bar{n}}{\alpha} \frac{\bar{n}}{\alpha} \frac{\bar{n}}{\alpha} \frac{\bar{n}}{\bar{\alpha}} \frac{\bar{n}}{\bar{\alpha}} \frac{\bar{n}}{\alpha} \frac{\bar{n}}{\alpha}$

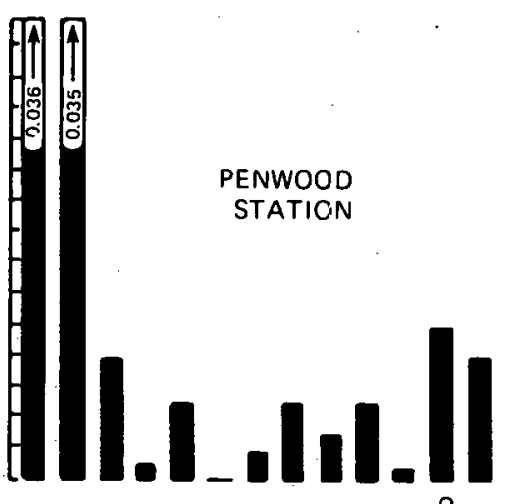

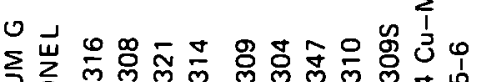

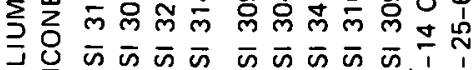

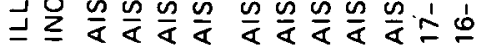

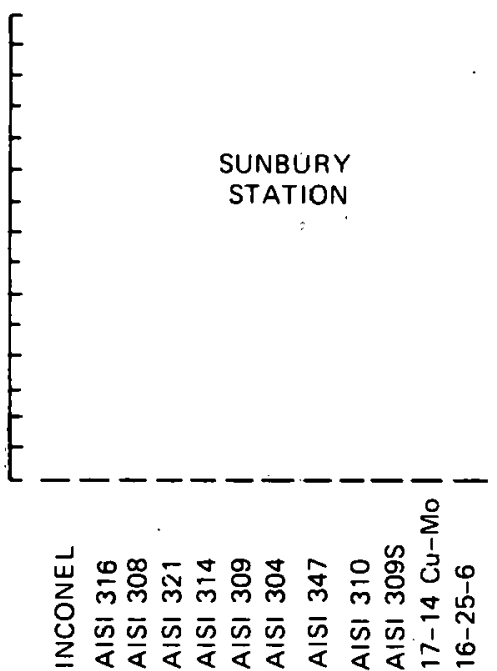

ORNL-OWG 78--2692
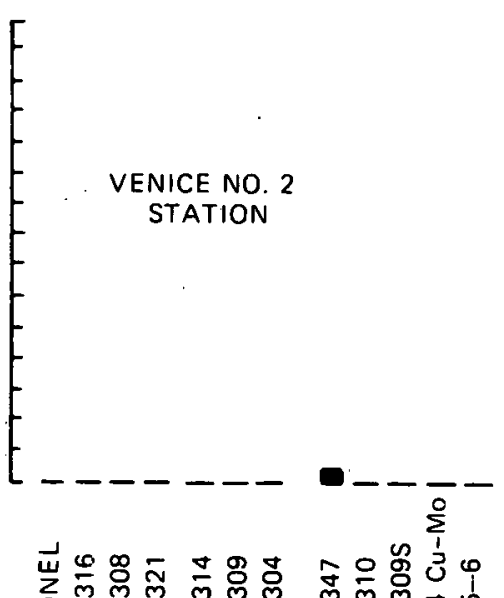
zल m

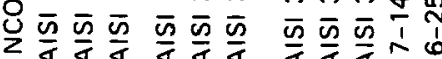

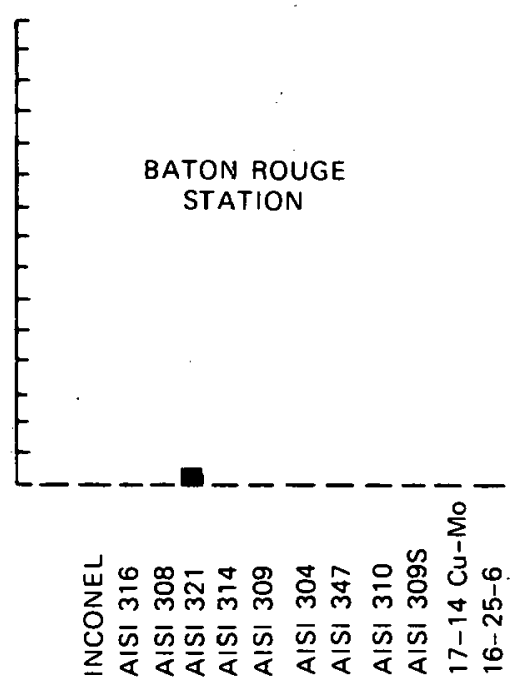

Fig. 9. Subsurface attack on test materials in various combustion atmospheres. ${ }^{4}$ 
Table 2. Test materials (from Ref. 43)

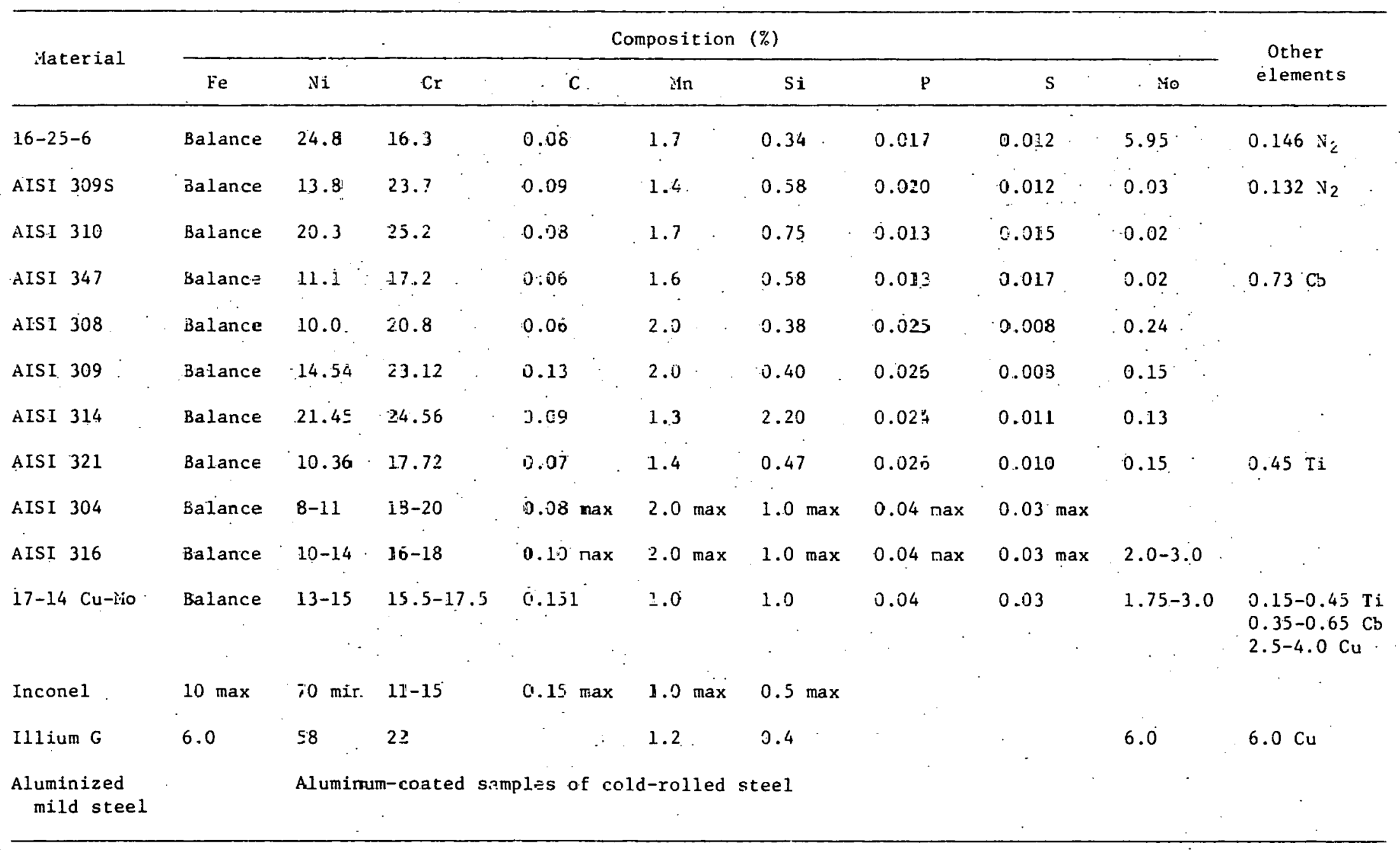


Table 3. Corrosion data for material exposed to varlous combustion atmospheres (Ref. 43)

\begin{tabular}{|c|c|c|c|c|c|c|}
\hline \multirow[b]{2}{*}{ Alloy } & \multicolumn{3}{|c|}{ H1gh-gulfur, h1gh-vanadlum fuel oll } & \multicolumn{3}{|c|}{ High-alkall content coke and blast-furnace gas } \\
\hline & $\begin{array}{c}\text { We1ght } \\
108 \mathrm{~g} \\
(\mathrm{~g} / 1 \mathrm{n} .2 / \mathrm{mo})\end{array}$ & $\begin{array}{l}\text { Decrease } \\
\text { in dlameter } \\
(\text { ipm })^{a}\end{array}$ & $\begin{array}{l}\text { Max. depth } \\
\text { subsurface } \\
\text { attack ( } \ln .)\end{array}$ & $\begin{array}{c}\text { Weight } \\
\text { loss } \\
(\mathrm{g} / \mathrm{in}, 2 / \mathrm{mo})\end{array}$ & $\begin{array}{l}\text { Decrease } \\
\text { in diameter } \\
(1 \mathrm{pm})^{a}\end{array}$ & $\begin{array}{l}\text { Max. depth } \\
\text { subsurface } \\
\text { attack (In.) }\end{array}$ \\
\hline & \multicolumn{3}{|c|}{ Sewaren Station } & \multicolumn{3}{|c|}{ Penwood Station } \\
\hline Aluminized steel & 1.451 & $b$ & None & 2.535 & $b$ & 0.008 \\
\hline Illium $G^{c}$ & 0.835 & 0.0062 & 0.002 & 1.290 & 0.0093 & 0.036 \\
\hline Inconel & 0.455 & 0.0032 & 0.009 & 1.762 & 0.0134 & 0.035 \\
\hline 17-14 Cu-Mo & $d$ & $d$ & $d$ & 1.808 & 0.0139 & 0.010 \\
\hline AISI 316 & 2.020 & 0.0156 & 0.006 & 0.785 & 0.0061 & 0.008 \\
\hline AISI 308 & 0.543 & 0.0042 & 0.001 & 0.618 & 0.0048 & 0.001 \\
\hline AISI 321 & 3.452 & $0.0266^{\circ}$ & 0.002 & 0.945 & 0.0075 & 0.005 \\
\hline AIST 314 & $0 . \varepsilon \varepsilon 7$ & 0.0068 & None & $0.078^{B}$ & 0.0006 & None \\
\hline AISI 309 & 0.681 & 0.0052 & None & 0.493 & 0.0038 & 0.002 \\
\hline AISI 304 & 1.439 & 0.0110 & None & 0.783 & 0.0061 & 0.005 \\
\hline AISI 347 & 1.492 & 0.0114 & 0.001 & 0.643 & 0.0049 & 0.003 \\
\hline AISI 310 & 0.310 & 0.0023 & None & $0.048^{e}$ & 0.0004 & 0.005 \\
\hline AISI $309 \mathrm{~S}$ & 0.183 & 0.0013 & None & $0.210^{e}$ & 0.0016 & 0.001 \\
\hline \multirow[t]{2}{*}{$16-25-6$} & $d$ & $d$ & $d$ & 0.810 & 0.0062 & 0.008 \\
\hline & \multicolumn{3}{|c|}{$\frac{\text { Natural gas and Illinols coal }}{\text { Venice No. } 2 \text { Station }}$} & \multicolumn{3}{|c|}{$\frac{\text { H1gh-sulfur ofl and gas }}{\text { Bayway Ref1nery }}$} \\
\hline $\begin{array}{l}\text { Aluminized steel } \\
\text { Illium } G^{\dot{c}}\end{array}$ & 0.099 & $b$ & None & 0.724 & $b$ & None \\
\hline Incone1 & 0.210 & 0.0015 & None & 1.860 & 0.0134 & None \\
\hline $17-14 \mathrm{Cu}-\mathrm{Mo}$ & 0.098 & 0.0008 & None & $d$ & $d$ & $d$ \\
\hline AISI 316 & 0.007 & 0.0001 & None & 1.216 & 0.0094 & None \\
\hline AISI 408 & 0.098 & 0.0008 & None & 0.063 & 0.0005 & 0.004 \\
\hline AISI 321 & 0.068 & 0.0005 & None & 0.896 & 0.0070 & 0.013 \\
\hline AISI 314 & 0.048 & 0.0004 & Nonne & 0.607 & 0.0048 & 0.003 \\
\hline AISI 309 & 0.203 & 0.0015 & None & 0.127 & 0.0010 & 0.005 \\
\hline AISI 304 & 0.195 & 0.0015 & None & 0.544 & 0.0042 & 0.013 \\
\hline AISI 347 & 0.128 & 0.0010 & 0.001 & 0.141 & 0.0011 & 0.003 \\
\hline AISI 310 & 0.000 & 0.0000 & None & 0.171 & 0.0013 & 0.001 \\
\hline AISI $309 \mathrm{~S}$ & 0.100 & 0.0007 & None & 0.067 & 0.0005 & 0.003 \\
\hline \multirow[t]{2}{*}{$16-2.5-6$} & 0.000 & 0.0000 & None & $d$ & $d$ & $d$ \\
\hline & \multicolumn{3}{|c|}{$\frac{\text { Low-sulfur anthracite coal }}{\text { Sunbury Station }}$} & \multicolumn{3}{|c|}{$\frac{\text { Sulfur-free natural gas }}{\text { Baton Rouge Station }}$} \\
\hline $\begin{array}{l}\text { Aluminized steel } \\
\text { Illium } G^{\theta}\end{array}$ & 0.62 & $d$ & None & 0.565 & $b$ & None \\
\hline Inconel & 0.0000 & 0.0000 & None & 0.0008 & 0.0001 & None \\
\hline 17-14 Cu-Mo & 0.0000 & 0.0000 & None & 0.0279 & 0.0002 & None \\
\hline AISI 316 & 0.0000 & 0.0000 & None & 0.1508 & 0.0012 & None \\
\hline AISI 308 & 0.0000 & 0.0000 & None & 0.0307 & 0.0002 & None \\
\hline AISI 321 & 0.0000 & 0.0000 & None & 0.2520 & 0.0020 & 0.001 \\
\hline AISI 314 & 0.0084 & 0.0001 & None & 0.0195 & 0.0002 & None \\
\hline AISI 309 & 0.0000 & 0.0000 & None & 0.0923 & 0.0007 & None \\
\hline AISİ 304 & 0.0218 & 0.0002 & Nuse & 0.0279 & 0.0002 & Nene \\
\hline AISI 347 & 0.0082 & 0.0001 & None & 0.0307 & 0.0002 & Nons \\
\hline AISI 310 & 0.01000 & 0,0000 & Nonè & 0.0081 & 0.0001 & None \\
\hline AISI $309 \mathrm{~S}$ & 0.0000 & 0.0000 & None & 0.0106 & 0.0001 & None \\
\hline $16-26-5$ & 0.0455 & 0.0003 & None & 0.0162 & 0.0001 & None \\
\hline
\end{tabular}

$a_{1 \mathrm{pw}}=$ inches per monich.

$b$ Due to uncertainty of densicy figure required in calculation, conversion to inches of radius logt per month could not be accomplished.

cNo specimens avaliable for 4 of 6 stations.

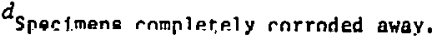

oslight pitting occurirèd. 
the corrosion rates varied from possibly acceptable to completely unacceptable with dirty fuel.

The principal forms of fireside corrosion attack are general oxidation of a surface and scaling on the one hand and sulfidation on the other. Sulfidation entails intergranular penetration of sulfur to form sulfides in the grain boundaries and these, of course, weaken the alloy. This form of attack is insidious in that the surface may appear to have suffered little attack yet the material may, have been severely weakened.

\section{Steam=8ide corrooion}

The rate of attack of ateels by higl-Lemperacure sccam is extremely sensitive to the oxygen content of the steam, and this in turn depends on the provisions for treating the feedwater. If the oxygen content can be kept extremely low - of the order of $7 \mathrm{ppb}$ - the corrosion rate of chromium-nickel alloys can be kept relatively low. ${ }^{44}$ Figure 10 shows

ORNL-DWG $78 \cdot 2693$

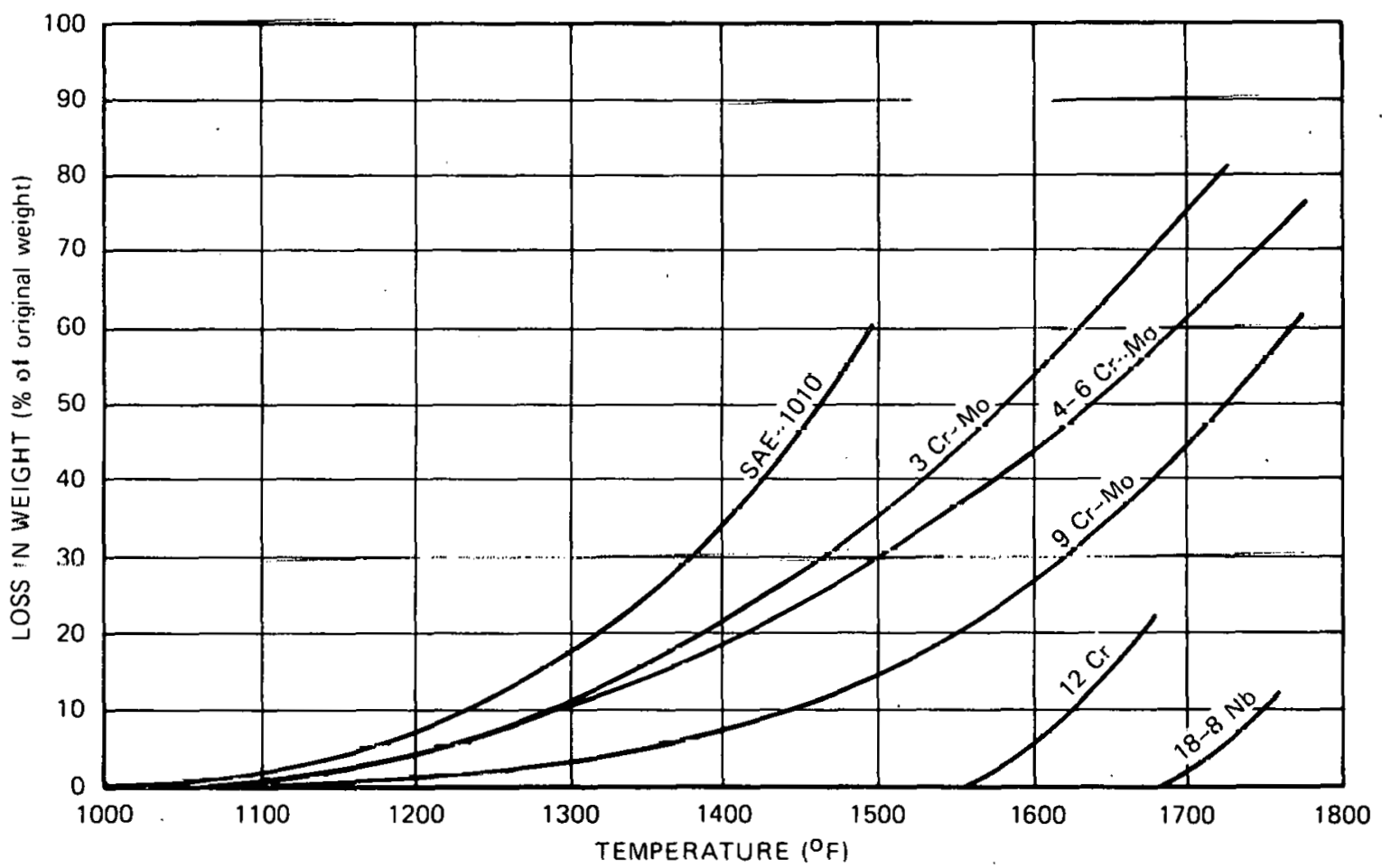

Fig. 10. Corrosion of steel bars in contact with steam for $500 \mathrm{hr}$ at various temperatures. 45 
the results of a set of tests in which the effect of temperature on the corrosion rates for typical alloys was investigated. 45 As one might expect, the corrosion rate increased fairly rapidly with temperature. This apparently occurs because steam tends to dissociate slightly at temperatures as $10 \mathrm{w}$ as $400^{\circ} \mathrm{C}\left(752^{\circ} \mathrm{F}\right)$ and the hydrogen tends to permeate through the steel leaving the oxygen to attack the steel surface. This was demonstrated in a classic set of tests carried out by Bloom et al. in which they employed an evacuated jacket around pipes carrying steam at a series of elevated temperatures. 46 Measurements of the hydrogen permeation rate into the jacket closely correlated with measurements of the oxidation attack of the interior of the tube walls by the hightemperature steam.

The austenitic stainless steels $(18 \% \mathrm{Cr}, 8 \% \mathrm{Ni})$ have been found to be highly subject to chloride corrosion. Chlorine concentrations in the feedwater of much less than 1 ppm can be concentrated in regions in which boiling occurs, so that local concentrations of chlorides can build up and cause severe intergranular corrosion. This problem has proved to be so troublesome in some types of service that austenitic stainless steels are not used; either ferritic Cr-Mo steels or a relatively high-nickel alloy such as Incoloy 800 are employed because they have been found to be insensitive to chloride corrosion.

High-temperature water tends to attack copper and lead which leads to deposits in the turbine. For this reason, copper alloys are excluded from the upper stages of the feedwater heating system.

Dissolved solids such as calcium carbonate and silica have always presented problems if present in feedwater, and they cannot be tolerated in once-through boiler systems. Thus, the modern steam plant must make use of a quite elaborate feedwater treatment system to assure the remova1 of essentially all dissolved solids together with oxygen and chlorine. 44 Very low concentrations of dissolved solids and oxygen are obtained by treatment with ion exchange resins, and the oxygen concentration is reduced further by additions of hydrazine. Typical values are given in Table 4. The resulting system is a major cost item and requires continuous attention from operating personnel. 
Table 4. Recommended concentrations

for once-through boilers (Ref. 44)

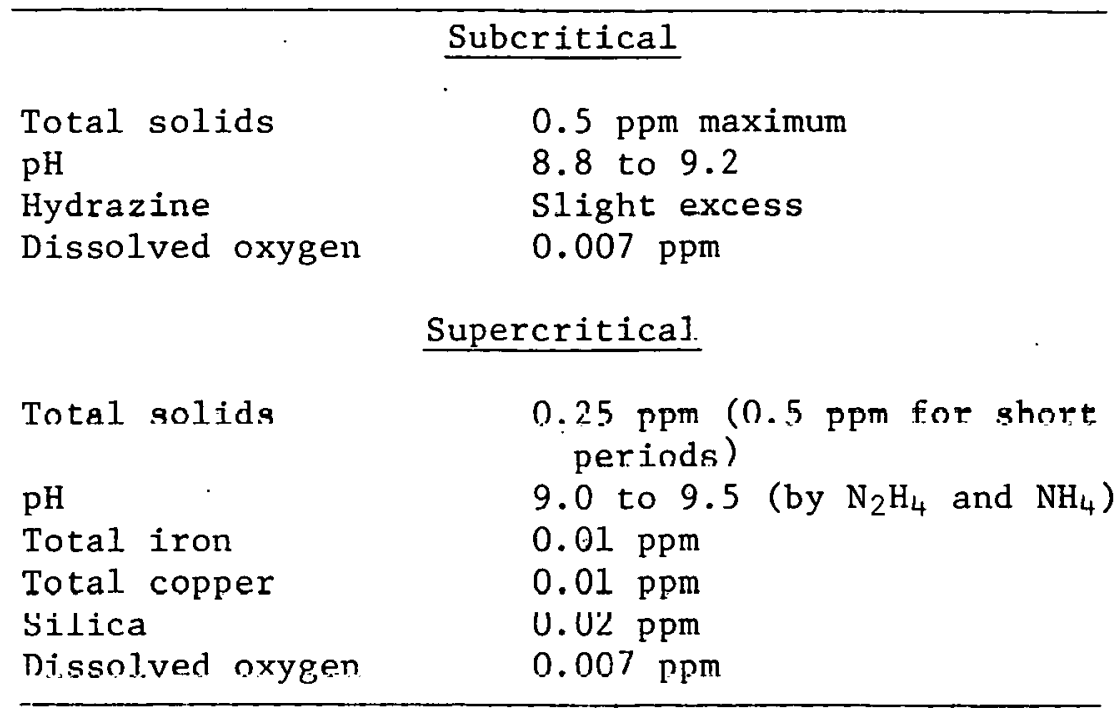

Design Parameters Affecting Efficiency and Cost

In designing a steam plant for minimum unit costs of electric power, numerous compromises must be made in efforts to balance improvements in thermal efficiency against increases in capital costs. These compromises differ depending on whether the plant is expected to be a base load plant, an intermediate load plant, or a peaking power plant. For example, base load plants normally employ peak steam temperatures of 538 to $565^{\circ} \mathrm{C}(1000$ to $1050^{\circ} \mathrm{F}$ ) whereas intermediate or peaking load plants commonly employ peak steam temperatures that are lower by 50 to $100^{\circ} \mathrm{C} .{ }^{47}$

\section{Plant thermal efficiency}

The thermal efficiency of a steam power plant is normally taken as the ratio of the useful electrical output delivered to the grid divided by the chemical energy available in the fuel. The principal component efficiencies commonly run around $90 \%$ for the boiler (the bulk of the loss is in the form of heat in the stack gases), aerodynamic losses in the turbine which give a turbine efficiency of 80 to $85 \%$, and heat losses inherent in the thermodynamic cycle (i.e., about $45 \%$ of the heat in the 
steam delivered to the turbine). Other smaller losses include electrical losses in the generator (about 1\%) and energy to the feed pumps ( 1 or $2 \%$ of the useful output). The power required to drive induced-and forceddraft fans and coal feed and preparation equipment, condensate pumps, condenser cooling water circulating pumps, and miscellaneous minor equipment totals about $3 \%$ of the plant net power output.

\section{Effects of peak steam temperature} on thermal efficiency

Any effort to increase plant thermal efficiency by increasing the steam pressure and/or temperature entails many compromises that must be made in an effort to avoid excessive increases in capital cost. A set of curves showing these effects is given in Figs. 11 and 12, taken from

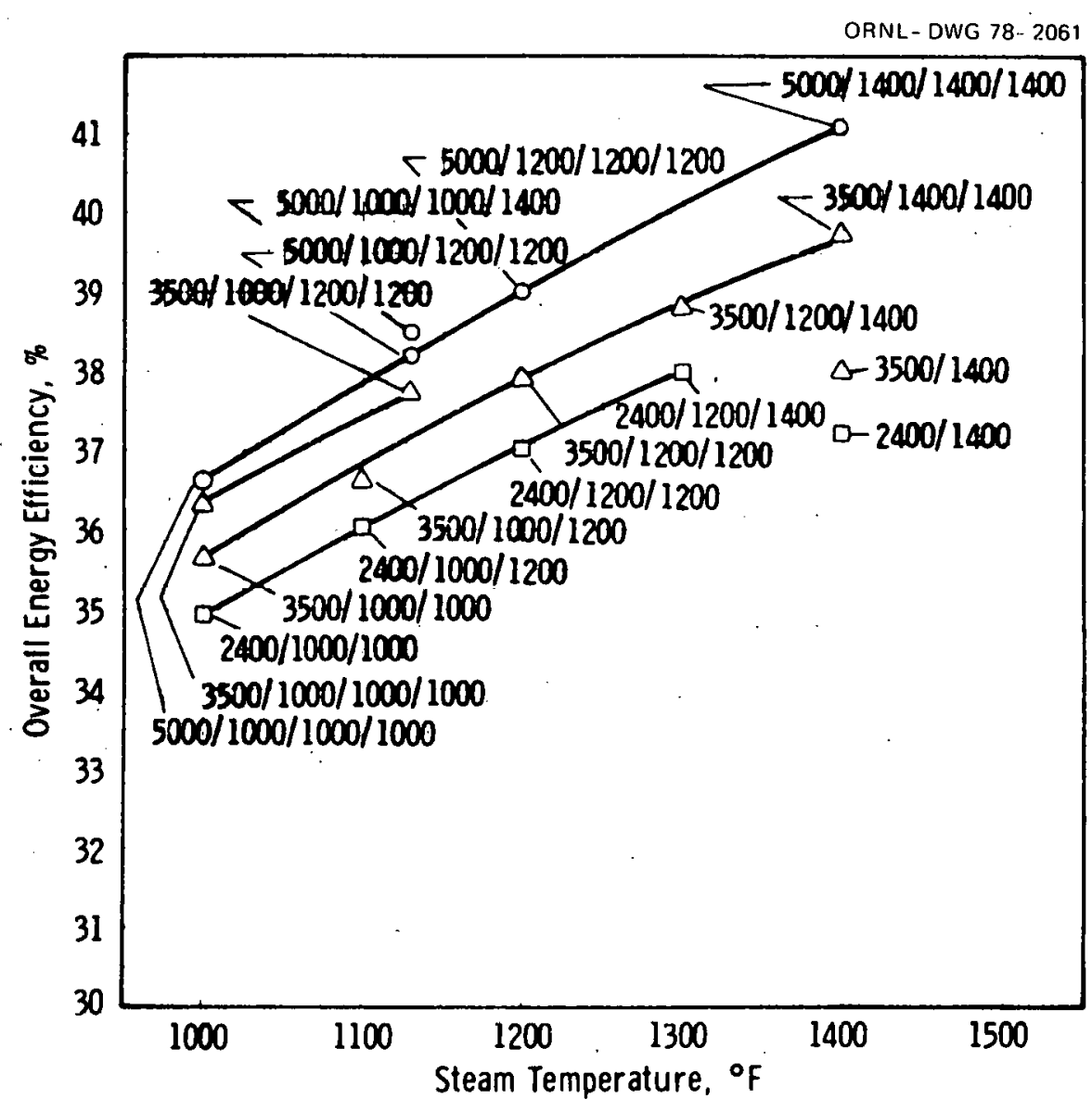

F1g. 11. Effect of steam throttle conditions on overall efficiency for a 500-MW(e) stean plant wlth an atimuspherlc furnace. 16 


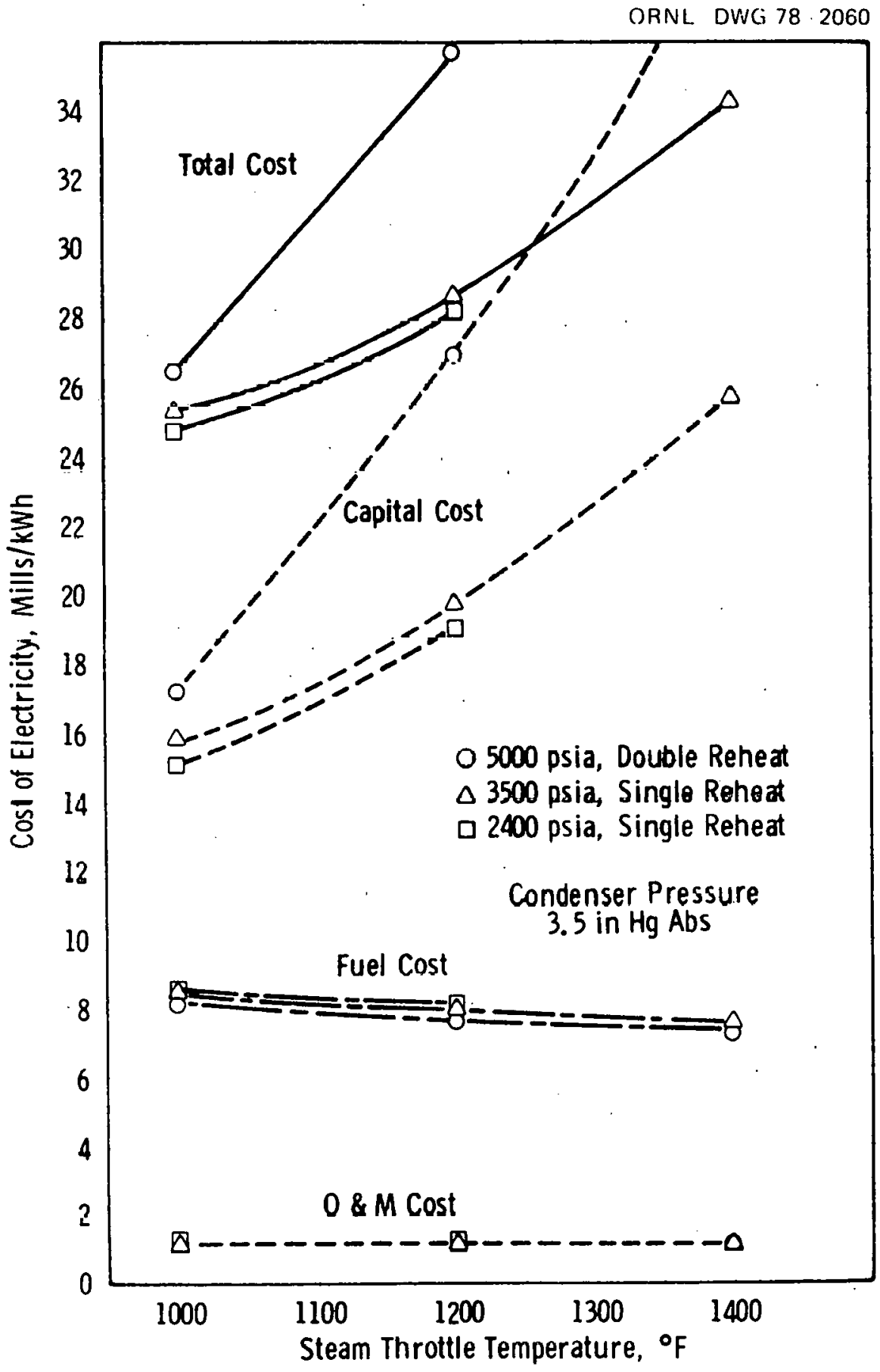

Fig. 12. Effect of steam turbine throttle conditions on the cost of electricity from a 500-MW(e) steam plant with an atmospheric furnace on the basis of 1975 dollars. 16 
the Westinghouse ECAS study. 16 Note the relatively small improvements in the thermal efficiency obtainable through the use of increased steam temperatures and pressures together with the relatively large increases in capital costs, so that the minimum cost of electricity is obtained with a peak steam temperature of about $538^{\circ} \mathrm{C}\left(1000^{\circ} \mathrm{F}\right)$. This result is consistent with numerous other studies that have been carried out in the past 25 years.

The curves of Fig. 12 suggest that the minimum capital cost of a plant would be found at steam pressures and temperatures lower than those considered in preparing Fig. 11. A review of the whole development of steam power plants shows that increasing the steam pressure and temperature from the low levels of the 1920's leads to reductions in the size of the furnace-steam generator for a given electrical output because of the higher thermal efficiency, similar reductions in the size of the condenser and condenser cooling water system, and reductions in the size and unit cost per kilowatt of electrical output for the combustion air and stack gas equipment. On the other hand, as is evident from Fig. 5, increasing the steam temperature beyond about $482^{\circ} \mathrm{C}\left(900^{\circ} \mathrm{F}\right)$ leads to a fairly rapid loss in strength of the relatively inexpensive low-alloy steels. The best resolution of the various compromises that must be made is indicated by the actual sales of steam plants for intermediate and peaking power purposes; 47 these plants are often designed for 60 to 120 bars ( 900 to $1800 \mathrm{psi}$ ) at 482 to $510^{\circ} \mathrm{C}\left(900\right.$ to $\left.950^{\circ} \mathrm{F}\right)$, with many having steam sonditions as 160 bars $(2400 \mathrm{psi})$ and $540 / 540^{\circ} \mathrm{C}\left(1000 / 1000^{\circ} \mathrm{F}\right)$.

\section{Effects of unit size on efficiency and cost}

Increasing the size of a unit leads to reductions in capital cost and small increases in efficiency stemming largely from the higher Reynolds numbers inherent in the larger sizes. An important savings in operating costs stems from the reduction in the amount of manpower required per unit of output; an increase in unit size by a factor of 10 commonly leads to an increase in manpower by only a factor of $\sim 6$. Other savings result from the fact that some components, such as instrumentation and control equipment, increase relatively little in cost and complexity as the unit size is increased. 
Effects of superheating and reheating

Superheating leads to an increase in the peak temperature in the cycle for a given peak steam pressure and this increases the thermal efficiency. The increase is not as great as one might expect from simple peak temperature considerations, because, as the amount of superheat is increased, the temperature-entropy diagram deviates farther and farther from the ideal rectangular Carnot cycle; this effect is shown in Fig. 13 . Reheating has the effect of giving a somewhat closer approach to the ideal Carnot cycle, again as can be seen in Fig. 13.

One of the most important reasons for employing superheat and reheat relatively early in the development of the steam power plant was that steam expansion in the turbine from a saturated steam condition leads to moisture formation, which in turn leads to turbine bucket erosion coupled with losses in turbine efficiency stemming from moisture churning energy losses. Refined design of the turbine blading to prevent the accumulation of liquid slugs in stagnation regions near the tips of stator blades, 48 coupled with bleedoff slots in the turbine casing and the use of bleedoff steam for regenerative feed heating, has greatly reduced the moisture churning losses and tendencies toward blade erosion. 49 In addition, the use of erosinn-resistant materials such as stellite and clcanlumin in the lower stages of the turbine has made it possible to increase the turbine tip speed in the last stage without getting into difficulty with serious moisture churning losses or turbine bucket erosion even when operating with saturated steam at the turbine inlet. 50

\section{Air preheat}

The principal loss from the furnace-steam generator unit is heat in the stack gas. By use of a rotary regenerator, a pronounced energy. savings can be effected by transferring heat from the stack gas to the incoming combustion air. Preheating the air also serves to improve combustion conditions and increases the temperature differcnce in the furnace and thus the heat flux. However, it has been found that $\mathrm{SO}_{2}$ in the stack gas combines with moisture to give highly corrosive sulfurous acid if the stack gas temperature is reduced below about $150^{\circ} \mathrm{C}\left(300^{\circ} \mathrm{F}\right)$. 

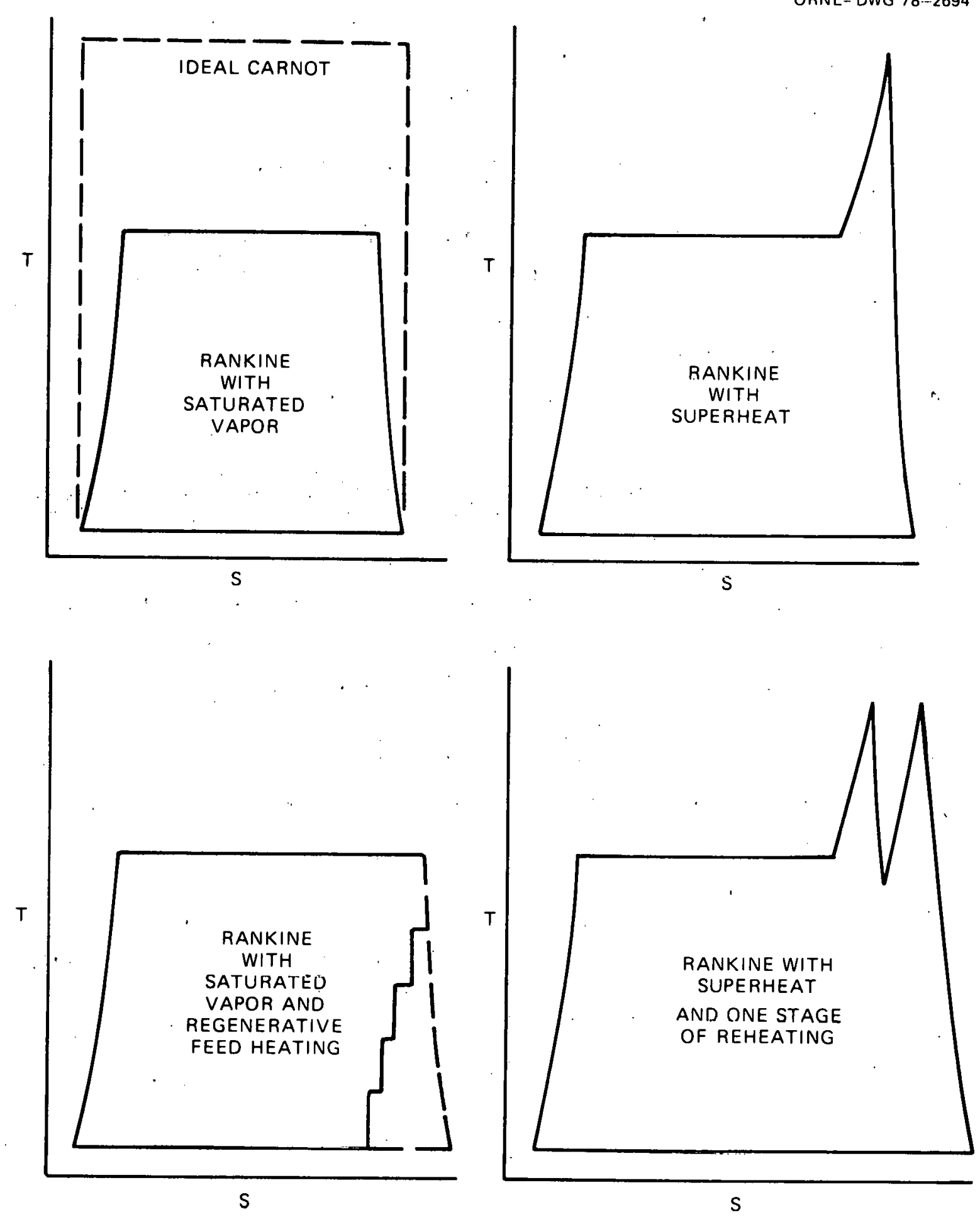

Fig. 13. Temperature-entropy diagrams for a typlcal set of Rankine cycles. 
It is also advantageous to have a substantial stack gas temperature $\left(\sim 150^{\circ} \mathrm{C}\right.$ ) both to give a good draft and to lift the plume of gas leaving the stack to an elevation perhaps double that of the height of the stack.

\section{Fluidized-Bed Coal Combustion Systems}

The most promising approach to improving the utilization of the energy in coal having an appreciable sulfur content for central station applications appears to be through the use of a fluidized-bed coal combustion system employing crushed limestone in the bed to capture the bulk of the sulfur. Although this system appears basically sound, the experimental record to date indicates that many basic technology problems must be solved before a useful commercial system can be buil,t. 25

\section{Fireside corrosion}

Probably the most important single set of problems involved in the use of a fluidized-bed coal combustion system is fireside corrosion. Operating experience with experimental units indicates that under some conditions there appears to have been no difficulty, whereas in others quite severe corrosion has been experienced.51-55 The problem is exceedIngly complex because so many different factors are likely to affect the corrosion rate, e.g., type of coal, the type of limestone, the calcium sulfur ratio, the fuel-air ratio, the air velocity through the bed and its influence on the bed operating regime (bubbly flow, turbulent flow, slugging), the bed operating temperature and pressure, the metal temperature, the type of alloy and coating or other treatment of the alloy. Further, the design of a particular bed may affert corrosion by influencing the bed operating regime; the turbulence in the bed and the uniformity of the lateral dispersion of fuel from the coal feed ports; the coal feed port spacing, which can be expected to influence the degree to which there may be local variations between oxidizing and reducing conditions; and bed depth. These problems can be investigated effectively only by carrying out experiments in a variety of fluidized beds under a wide range of test conditions. 


\section{Effects of furnace pressure}

Almost all the work to date in the U.S. on experimental systems has been directed toward atmospheric pressure beds. Design studies ${ }^{30-36}$ indicate that the capital cost of atmospheric pressure fluidized-bed furnaces coupled to steam generators may be sufficiently higher than the capital cost of a conventional coal-fired steam generator that one could afford to use the latter with low-sulfur coal at $\$ 45 /$ ton (vs $\$ 25$ a ton for high sulfur coal).

It was recognized early in the fluidized-bed development program that pressurizing the furnace would reduce both the capital cost of the furnace and steam generator tube matrix and the number of coal feed points. This approach has proved so attractive that many studies have been directed at this possibility, generally using a furnace pressure of w10 atm with the furnace serving as the combustion chamber for a gas turbine.16,29 W1th this arrangement a substantial amount of useful electrical power output can be obtained (in principle) from the gas turbine. However, as will be discussed in the next section, over 30 years of effort has yet to produce a coal-fired gas turbine that would operate at $650^{\circ} \mathrm{C}$ $\left(1200^{\circ} \mathrm{F}\right)$ or more for extended periods without serious difficulties with turbine bucket erosion and/or deposits.37,38 Thus, it appears worthwhile to consider the use of a furnace supercharged to 3 to $5 \mathrm{~atm}$ with an exhaust turbosupercharger in which the hot gas would flow to the turbine at $2540^{\circ} \mathrm{C}\left(1000^{\circ} \mathrm{F}\right)$ to give just enough output to drive the compressor but would not provide any useful power. ${ }^{33}$ Thirty-four furnaces of this type were built for the Navy in the 1960's and have been giving excellent performance and reliability in naval destroyers. 56,57 Analyses and design studies indicate that this approach would cut both the capital cost of the fluidized-bed furnace-steam generator unit and the number of coal feed ports. Further, it would permit increasing the fluldized-bed depth from the roughly $1 \mathrm{~m}$ characteristic of atmospheric fluidized bed units to about $3 \mathrm{~m}$ and increase the transit time for small particles of coal and limestone as they pass through the bed; thus the amount of unburned carbon in the ash particles elutriated from the bed could be reduced and the utilization of the limestone should be improved. 
An especially important advantage of the deep beds associated with pressurizing the furnace is that vertical rather than horizontal boiler tubes can be employed, thus greatly easing the tube support problem and the accommodation of differential thermal expansion between the hot boiler tubes and the cooler structure of the furnace shell.

\section{Erosion and deposits in coal-fired gas turbines}

The reductions in furnace size and cost obtainable by pressurizing the furnace have been recognized for a long time, as has the possibility of keeping the pumping power requirements reasonable by making the furnace act as the combustion chamber for an open-cycle gas turbine. 58,59 in recent years design studies of such systems have usually contemplated turbine inlet temperatures of around $870^{\circ} \mathrm{C}\left(1600^{\circ} \mathrm{F}\right) .16,29,59$ Unfortunately, over 30 years of experience with coal-burning gas turbines indicates that turbine bucket erosion, corrosion, and deposits have proved so serious that no one has yet succeeded in operating such units for more than some hundreds of hours prior to a forced outage for at lcast a cleaning operation. ${ }^{37,38}$ One key to redured erosion appearc to bc a reduction in turbine inlet temperature to give an increased hardness of the blade material. A study of this problem, presented in Ref. 60 and summarized in Fig. 14, has shown good correlation hetween the erosion rate and the ratio of the melting point to the modulus of elasticity. A review of data on the latter parameter for $\mathrm{Fe}-\mathrm{Cr}-\mathrm{Ni}-\mathrm{Co}$ alloys indicates that dropping the temperature from 871 to $538^{\circ} \mathrm{C}\left(1600\right.$ to $1000^{\circ} \mathrm{F}$ ) increases the modulus of elasticity by 30 to $60 \%$. Figure 14 indicates that such an increase in the modulus should reduce the ernsion rate by a factor of about 10 .

The bulldup of deposits in a coal-fired gas turbine apparently stems from the presence in the ash of a small fraction that is close enough to its melting point so that it is plastic (like red-hot glass) and tends to fuse to metal. surfaces. This sticky material furms a f1lm on the blade surfaces and gives a "fly-paper" effect in that it accumulates higher melting point particles. The result is a buildup of hard ceramic deposits. An excellent insight into the effects of both low-melting 


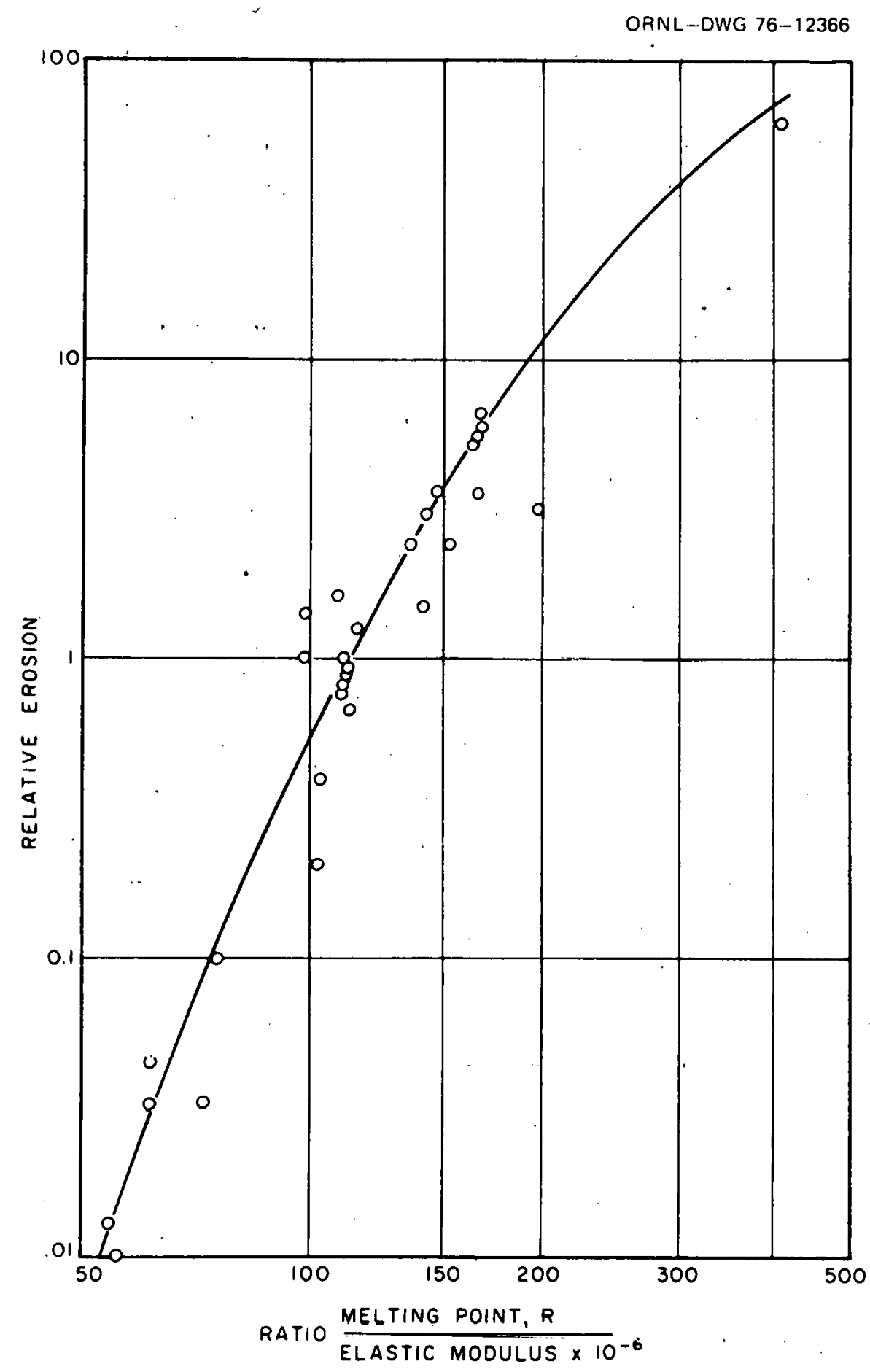

Fig. 14. Correlation of erosion with ratlo of melting point to elastic modulus. 60 
constituents in the ash and the turbine inlet temperature on ash deposits in the turbine was obtained in Australia in a test rig designed to simulate turbine conditions. 61 Tests were carried out both with ash from a typical Australian coal and with Mgo containing low-melting salts that would serve as bonding agents, i.e., give a "fly-paper" effect of the sort noted in Bureau of Mines tests of the coal-fired locomotive gas turbine. 62 Figure 15 shows the results of this set of controlled experiments. Perhaps the most significant point to note with respect to the questions of immediate interest is that the deposits formed from the Yalbouru coal dropped rapidly with a reduction in temperature to practically zero at $500^{\circ} \mathrm{C}\left(932^{\circ} \mathrm{F}\right)$. Note, too, that pure Mgo with no binding agent also gave almost no deposits at $600^{\circ} \mathrm{C}\left(1112^{\circ} \mathrm{F}\right)$. However, the addition of a low-melting salt in the form of sodium, pntassium, or magncaium chloride or eutectic mixtures of these materials led to both heavier deposits and a decrease in the temperature at which a low deposition rate was observed.

A review of experience with gas turbines employed with petroleum catalytic cracking units,63,64 fuel oil having an appreriable ash content; blast furnace gas, ${ }^{65}$ and gas from coal gasification units is consistent with the above statements. Note particularly that 40 years of work with gas turbines running on blast furnace gas has shown that this gas must be cooled and cleaned with two stages of water scrubbers before feeding it to the burners in order to keep turbine erosion and deposits to an acceptable level for operation with turbine inlet temperature of $\sim 730^{\circ} \mathrm{C}$ $\left(1350^{\circ} \mathrm{F}\right)$.

Particulate removal from hot gas streams

$\Lambda$ roview of the varluue papcrs in the lilerature indicates that in catalytic cracking units the particulate loading in the gas entering the turbine can be as high as $100 \mathrm{ppm}$. This presumes that the particle size can be kept below $10 \mu \mathrm{m}$, the temperature of the particulate material is well below its softening point, the turbine blades are stellite and coated with tungsten carbide, the turbine inlet temperature is below $650^{\circ} \mathrm{C}\left(1200^{\circ} \mathrm{F}\right)$, a turbine life of 2 years is acceptable, and the air 
ORNL--DWG 76-12367R

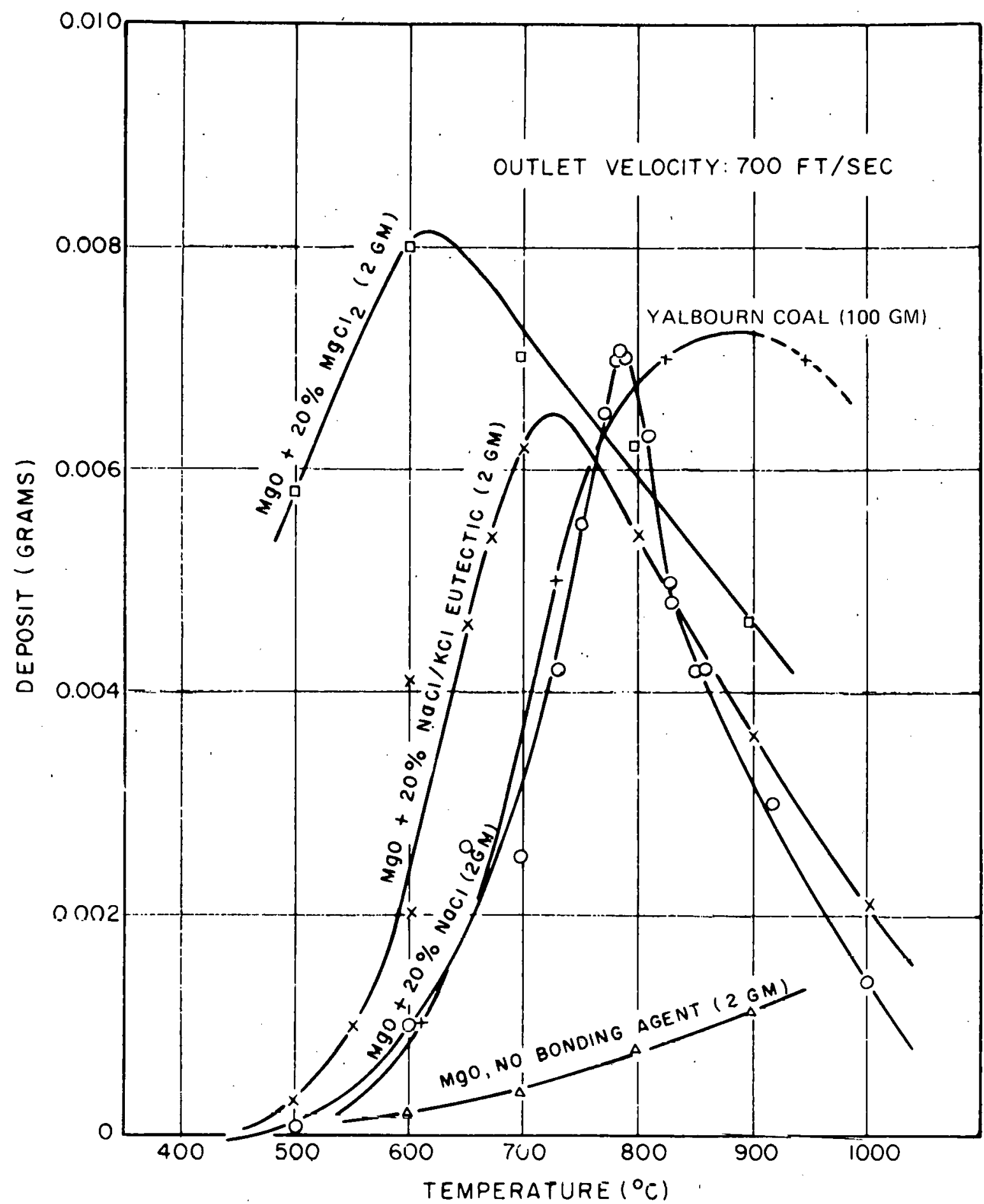

Fig. 15. Effects of temperature on the deposition rate of both coal ash and varlous mixtures of $\mathrm{MgO}$ and chlorlde salts fed into the hot gas stream of a turbine simulation test rig in Australia. The particle size was nominally $5 \mu \mathrm{m} .{ }^{64}$ 
flow conditions entering the turbine are such that the dust particles. are uniformly mixed so that the damage is uniformly distributed. 63 The experience generally indicates that it is possible to keep the particulate content down to $20 \mathrm{ppm}$ with dust separators that depend on centrifugal force, but the last of three-stage separation units must make use of a more elegant air flow passage geometry than conventional cyclone separators.63,64 Further, these separators must be effective at removing virtually all particles larger than $10 \mu \mathrm{m} .{ }^{64}$ However, it is difficult indeed to get a uniform dust distribution in the air entering the turblne; this can be accomplished only with a long axial. inflow pipe encering a single-stage overhung turbine rotor. ${ }^{63}$ Further, the axial inflow pipe must be much larger than the turbine rotor inlet and the passage contours at the turbine inlet must be such that an excellent velocity distribution is obtained. Such a design is possible only for a turbine driving a compressor or if the turbine produces relatively little electrical power, so that only one stage is required. If the gas stream must enter the turbine from the side, dust particles tend to concentrate in a relatively small fraction of the perimeter and lead to severe erosion or deposits in that region. For such cases, the particulate loading normally must be kept to around 1 ppm* if deposits and erosion are to be kept to an acceptable leve] for a turbine inlet temperature of the order of $700^{\circ} \mathrm{C}$ $\left(1292^{\circ} \mathrm{F}\right)$. It has not been found possible as yet to get a particulate content this low with cyclone particle separators; much more elaborate equipment will be required. Electrostatic precipitators do not work well above about $540^{\circ} \mathrm{C} .\left(1000^{\circ} \mathrm{F}\right)$, partly because ceramic insulators for the high tension grids become conducting. Granular bed filters are being investigated, $66-68$ but the results to date have not been promising (the filters are clogged by the finc particlet removed from the gas stream).

\section{Control of fluidized-bed steam generators}

Hundreds of fluidized-bed combustion eystems are in use commercially to burn low-grade solid waste such as sawdust and sludge from sewage

$*_{1} \mathrm{ppm}=1.22 \mathrm{mg} / \mathrm{m}^{3}=0.0345 \mathrm{mg} / \mathrm{ft}^{3}=0.00054 \mathrm{grain} / \mathrm{ft}^{3}$. 
plants, while hundreds of other units are in commercial operating roasting pyrite ores. In view of this, it is surprising that there are no fluidized-bed coal combustion systems in commercial operation with steam boilers, although quite a number of small experimental units have been operated during the past 20 years. Probably the most important reason for this situation is that there have been serious problems in controlling the combination of a fluidized-bed coal combustion system and a steam boiler with its tubes immersed in the bed. The problem is particularly important now because of the Clean Air Act; burning coal in a fluidized bed of limestone in the temperature range between 816 and $927^{\circ} \mathrm{C}(1500$ and $1700^{\circ} \mathrm{F}$ ) should allow removal of about $90 \%$ of the sulfur as calcium sulfate in the course of combustion, but to do this about two-thirds of the heat released by combustion of the coal must be removed from the fluidized bed by a tube matrix immersed in the bed and herein lies the crux of the problem.

The heat transfer coefficient between the bed and the tube wall is high - around $300 \mathrm{~J} / \mathrm{sec} \rightarrow \mathrm{m}^{2}-{ }^{\circ} \mathrm{C}\left(\sim 50\right.$ to $\left.60 \mathrm{Btu} / \mathrm{hr}-\mathrm{ft} \mathrm{t}^{2}-{ }^{\circ} \mathrm{F}\right)$. At the same time, the heat transfer coefficient from the tube to the boiling water under nucleate boiling conditions is very high - of the order of 30,000 $\mathrm{J} / \mathrm{sec}-\mathrm{m}^{2}-^{\circ} \mathrm{C}\left(\sim 5000 \mathrm{Btu} / \mathrm{hr}-\mathrm{ft}^{2}-^{\circ} \mathrm{F}\right)$. Thus, the tube wall tends to run close to the water temperature. Both the fluid bed-side and the waterside coefficients are essentially independent of the combustion gas and water flow rates, respectively. Inasmuch as $\mathrm{Q} / \mathrm{A}=\mathrm{u} \Delta \mathrm{T}$ and the overall heat transfer coefficient $u$ is constant, if one attempts to reduce the rate of heat release in the bed, the bed temperature will drop unlil it reaches about $480^{\circ} \mathrm{C}\left(900^{\circ} \mathrm{F}\right)$, at which point the bed will quench (i.e., "the fire will go out"). If the coal feed is continued, coke will form and clog the bed. If the water flow to the boiler is reduced in an effort to keep the bed temperature constant at reduced outputs of $2870^{\circ} \mathrm{C}$ $\left(1600^{\circ} \mathrm{F}\right)$, the water-side heat transfer mechanism shifts from a nucleate boiling condition to a vapor film blanket condition. This effect is illustrated by Fig. 16, which shows a typical curve for the heat flux to boiling water as a function of the temperature difference between the boiling point of the water and the metal wall from which the heat is 


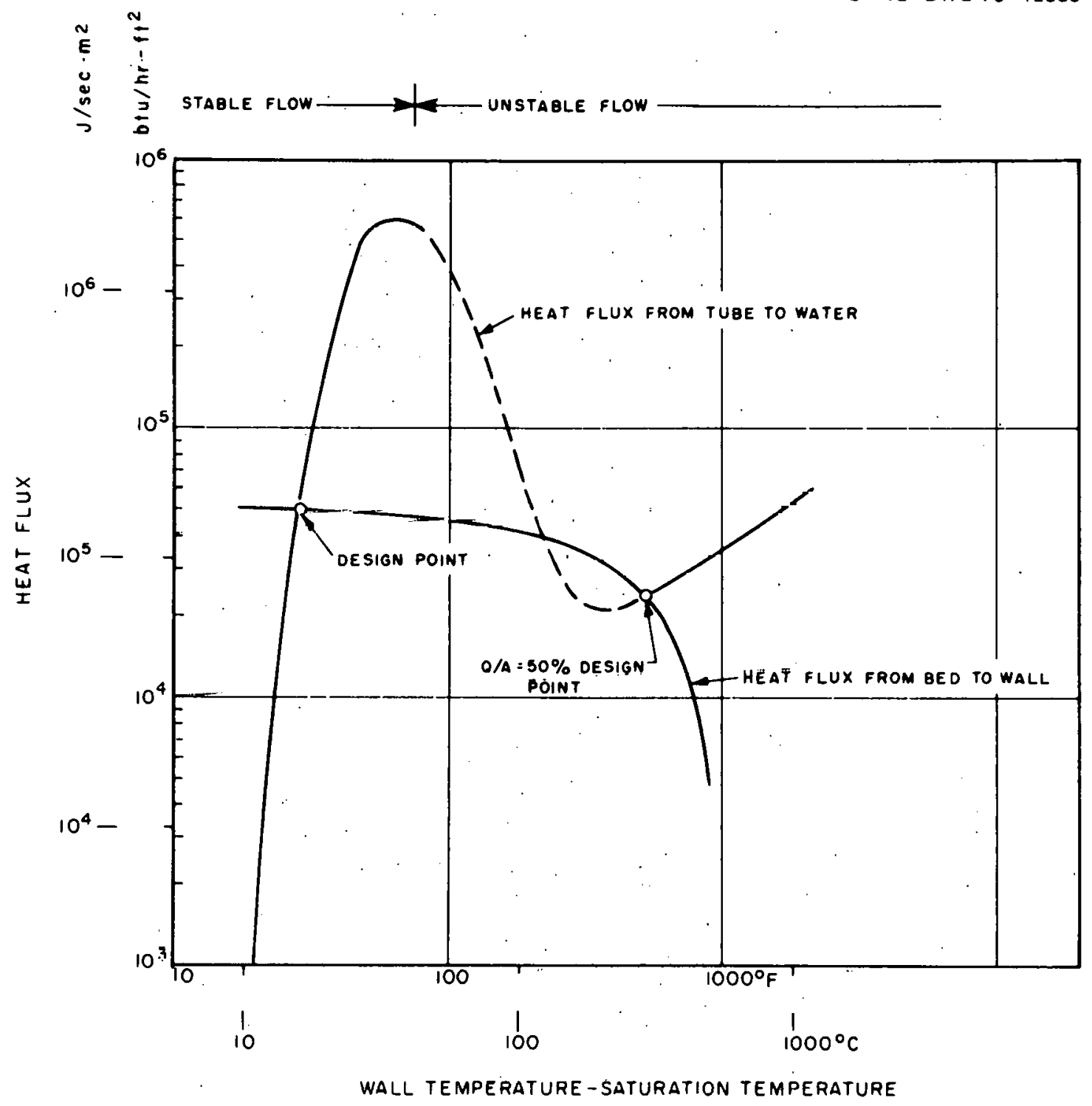

Fig. 16. Heat flux in a fluidized-bed steam boller with a bed temperature $1000^{\circ} \mathrm{F}\left(555^{\circ} \mathrm{F}\right)$ above the saturation temperature assuming a typical curve tor the heat flux to boiling water.

being conducted. 69 If the fluidized-bed temperature is held at $870^{\circ} \mathrm{C}$ $\left(1600^{\circ} \mathrm{F}\right)$ and the metal tube wall at $316^{\circ} \mathrm{C}\left(600^{\circ} \mathrm{F}\right)$, the heat flux through the tube wall under normal. nucleate boiling cunditions would run about

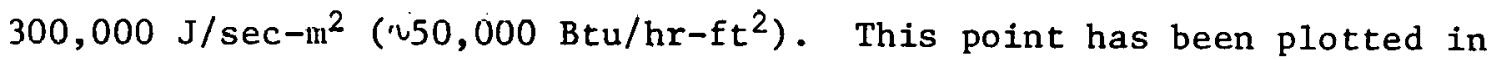
Fig. 16 to indicate the normal operating point to be expected. Note that operation in this region is stable; i.e., any small increase in the 
tube wall temperature will result in a greatly increased heat flux from the tube wall to the boiling water so that the operating condition is eminently stable. If one attempts to reduce the heat flux from the bed to the tube wall by allowing the tube wall temperature to increase to say $540^{\circ} \mathrm{C}\left(1000^{\circ} \mathrm{F}\right)$, the heat flux will be cut roughly in half, but the heat transfer mode will be via vapor blanket boiling which will be very unstable and lead to wide fluctuations in the local metal temperature. Even worse, the water flow rate through the tube will become highly unstable and lead to even more severe temperature fluctuations and thermal stresses. Thermal strain cycling failure of the tubes will result if the tubes do not overheat so much that their loss in strength leads to failure from pressure stresses. Note that this unstable operating region is indicated in Fig. 16 and that intermediate conditions between these two regions would be unstable because any small increase in the tube wall temperature would lead to a reduction in the heat flux from the tube wall to the boiling water.

For good reliability, operation must be constrained to the nucleate boiling regime with a fixed bed temperature of around $870^{\circ} \mathrm{C}\left(1600^{\circ} \mathrm{F}\right)$. Basic heat transfer considerations indicate that the only good way to reduce the heat input to the boiler is to reduce the amount of surface area of the tube matrix immersed in the bed. This in turn implies that either the bed should be compartmentalized so that the output can be changed in quantum jumps or the level of the fluidized bed should be varied. The former approach presents difficulties in the relative phasing of the flow of red-hot "sand" and feedwater to a compartment being activated or deactivated. Unless this phasing is carried out properly one runs the danger either of chilling the bed in that region and building up heavy coke deposits or of getting into a vapor blanket boiling region, generating hot spots in the tubes, and failure of the tubes after a series of perhaps 10 to 100 thermal cycles.

Varying the bed depth presents a problem in that it is difficult to determine where the surface of the bed is when in operation because in the regime of interest the fluidized bed will be bubbling violently. Fixperiense at the British Coal Utilization Research Association laboratory in England indicates that the bed depth can be determined and controlled 
within 7 to $10 \mathrm{~cm}$ ( 3 or 4 in.) by measuring the pressure drop across the bed. For an atmospheric fluidized bed for which the maximum bed depth with an acceptable pumping power loss would be around $1 \mathrm{~m}$ (40 in.), the uncertainty in bed depth would be around $10 \%$ of the bed depth at full power and progressively greater if the bed depth were reduced at part power. This would make control difficult. If on the other hand the bed depth at full power. is made around $3 \mathrm{~m}$ ( $10 \mathrm{ft}$ ), the uncertainty in depth becomes only a few percent and provides a good basis for the control of the power output. 'lhat is, the power output will not be too sensitive to modest additions or removal of "hot sand" to or from the bed.

\section{CURRENT STATUS OF DEVELOPMENT}

As in the previous section, attention here will be directed toward work on fluidized-bed coal combustion because the rest of the R\&D work on steam systems is concerned with refinement of existing equipment to effect small incremental improvements in its reliability or effectiveness. Only the fluidized-bed effort involves both major uncertainties and the possibility for a major payoff.

The development work on fluidized-bed coal combustion systems was confined to only a few scattered small-scale efforts up until 1972, when the implications of U.S. Federal Government regulations on air quality became apparent and the developing shortages of natural gas and petroleum greatly increased the incentives to utilize coal, particularly coal containing appreciable amounts of sulfur. Thus, there was a large expansion in efforts to design fluidized-bed coal combustion systems coupled to steam generators, and this led to numerous efforts to design and build small experimental facilities aimed at resolving the many questions that became apparent in the design studies.

\section{Experimental Facilities}

The development of flutdized-bed combustion systems is so heav1ly dependent on the experimental resolution of several complex problems that it seems best at this point to summarize the experimental facilities 
that have been built or at least designed and funded for construction in the U.S. and Great Britain. Table 5 summarizes the principal parameters and gives the size and capacity of these experimental units. Note that only two of these are large enough to be considered demonstration plants; most are units $30 \mathrm{~cm}(1 \mathrm{ft})$ or less in cross section. The column at the extreme right giving the amount of running time on each of these units is indicative of the amount of information that has been obtained in each case. In fact, most of the running time to date in most of the systems that have been built has been concerned with shakedown problems. The results of the test experience are summarized in the last section of this report.

\section{Design Studies}

Many design studies of fluidized-bed coal combustion systems have been prepared, most of them involving fluidized beds coupled to steam. generators.16,29-36,68,70 The principal value of these studies is that, when examined critically, they point up the need for the experiments called for in the earlier section on recommendations. If satisfactory results are obtained in the experiments, particularly those concerned with fireside corrosion, the design studies indicate that the fluidizedbed coal combustion system coupled to a steam generator should lead to both reduced capital costs and improved thermal efficiency.

\section{EXPERIENCE IN SYSTEM R\&D WORK}

It appears that the best way to present the results from experimental work on fluidized-bed coal combustion is to summarize the information available in each of the major problem areas rather than to review the results of each of the different laboratories working in the field.

\section{General Operating Characteristics}

In general, there has been little trouble with operation of the fluidized bed itself other than in getting good control over a wide range 
Table 5. Characteristics of fluidized-bed coal combustion systems

\begin{tabular}{|c|c|c|c|c|c|c|c|c|c|}
\hline \multirow{2}{*}{ Organization } & \multirow{2}{*}{$\begin{array}{l}\text { Furnace } \\
\text { pressure } \\
\text { (atm) }\end{array}$} & \multirow{2}{*}{$\begin{array}{l}\text { Bed area } \\
\left(\mathrm{ft}^{2}\right)\end{array}$} & \multirow{2}{*}{$\begin{array}{l}\text { Bed depth } \\
\text { (ft })\end{array}$} & \multirow{2}{*}{$\begin{array}{l}\text { Superficial } \\
\text { velocity } \\
\text { (ft/sec) }\end{array}$} & \multicolumn{2}{|c|}{ Power outpdt } & \multirow{2}{*}{$\begin{array}{c}\text { Output } \\
\text { per } \mathrm{ft}^{2} \\
{\left[\mathrm{~kW}(\mathrm{t}) / \mathrm{ft}^{2}\right]}\end{array}$} & \multirow{2}{*}{$\begin{array}{c}\text { Power } \\
\text { density } \\
{\left[\mathrm{kW}(\mathrm{t}) / \mathrm{ft}^{3}\right]}\end{array}$} & \multirow{2}{*}{$\begin{array}{l}\text { Total } \\
\text { running } \\
\text { time } \\
\text { (hr) }\end{array}$} \\
\hline & & & & & $M W(t)$ & Bt-a!hr & & & \\
\hline Pope, Evans: \& Robbins & 1 & 10 & 3 & 10 & & $6.8 \times 10^{5}$ & & . & 25000 \\
\hline Foster-Wheeler & 1 & 2 & 3 & 10 & & $1.4 \times 10^{6}$ & & . & 25000 \\
\hline Rivesville & 1 & 456 & 3 & 10 & 88 & $3 \times 10^{3}$ & 192 & .64 & 21700 \\
\hline $\begin{array}{l}\text { BCURA } \\
\text { (Leatherhead) }\end{array}$ & 6 & 6.25 & 4 & 2.4 & 1.68 & & 280 & 47 & $210^{4}$ \\
\hline $\begin{array}{l}\text { Coal Research Labs } \\
\text { (Stoke Orchard). }\end{array}$ & 1 & 0.78 & . & & & & $\therefore$ & & $210^{4}$. \\
\hline B\&W - Renfrew & 1 & 130 & & & & & & & 23000 \\
\hline Combustion Power & 6 & 38.9 & 2.7 . & 4.4 & $4^{\circ}$ & & 103 & 38 & 500 \\
\hline Argonne National Lab. & 1 & 0.2 & $2-5$ & $3-8$ & 0.0175 & $60 \times 10^{2}$ & 88 & 9 & $210^{3}$ \\
\hline Argonne National Lab. & 10 & 0.2 & $2-5$ & $3-8$ & 0.175 & $60 \times 10^{4}$ & 880 & 88 & $210^{3}$ \\
\hline Exxon Research & 10 & 0.8 & 10 & & & & & & 22000 \\
\hline MERC & 1 & 1.7 & 3 & 3 to. 4.5 & & & 73 & & $210^{3}$ \\
\hline Fluidyne & 1 & 2.25 & 3 & 2 to 4.0 & 0.15 & $5 \times 10^{3}$ & 66 & 22 & 21500 \\
\hline FluiDyne & 1 & 17 & 3. & 2 to 4.0. & 1.2 & $40=10^{3}$ & 66 & 22 & 500 \\
\hline B\&W - Barberton. & 1 & 9 & . & & & & & & \\
\hline B\&W - Barberton & 1 & 36 & & & . & - & & . & ' \\
\hline Dorr-0liver & 1 & 0.8 & & & & &. & & \\
\hline Curtiss-Wright & 7 & 7 & & & & & & & \\
\hline ORNL & 1 & 36 & 3 & 2.1 & 1.5 & . & 41 & 13.7 & 0 \\
\hline MERC & 1 & 36 & 3 & & & & & & 0 \\
\hline
\end{tabular}


of power conditions; most of the difficulties have been concerned with auxiliary components such as the fuel metering and feed system. Generally, the work, as one might expect, indicates that the fluidized-bed air flow rate should be increased to the point where the bed is bubbling smoothly and has been heated to at least $500^{\circ} \mathrm{C}\left(930^{\circ} \mathrm{F}\right)$ before beginning the injection of coal. The experience also indicates that. the air flow rate through the bed can be increased by about a factor of 3 before excessive elutriation becomes a problem. Most operators prefer to keep the superficial velocity of the gas leaving the bed to less than $2 \mathrm{~m} / \mathrm{sec}(7 \mathrm{ft} / \mathrm{sec}$ ), although a few have favored velocities nearly double that. The attrition rate of both the lime and the ash increases fairly rapidly with the superficial gas velocity; this increases the stack gas cleanup problem, which is becoming increasingly important as environmental studies indicate the deleterious effects of submicron-size particles. Further, at the higher velocities, the carry-over of unburned carbon runs 10 to $20 \%$ of the fuel feed so that the coarser material collected by the first-stage cyclone separator must be recycled either to the bed or to a special carbon burnup cell. (The finer material collected by the second-stage cycle contains. much less unburned carbon.) Marked increases in hed depth made possible by pressurizing the bed should greatly increase the transit time through the bed and hence the fraction of the carbon burned before particles are elutriated from the top of the bed. This may obviate the need for recirculation of the material collected by the first-stage cyclone.

\section{Sulfur Retention}

Much of the operation of fluidized beds in the past seven years has had the determination of the effect of major parameters on sulfur retention as a major objective. Investigations have included the effects of calcium-sulfur ratio, excess air, bed operating temperature, type of, coal, type of limestone or dolomite employed, particle size, and furnace pressure. In general, the results indicate that as much as $90 \%$ of the sulfur can be retained in the bed for a calcium-sulfur ratio between 2 
and 3 at a bed operating temperature of $870^{\circ} \mathrm{C}\left(1600^{\circ} \mathrm{F}\right)$. The optimum temperature for sulfur retention increases with increasing pressure, but the percent retained is not too sensitive to the bed operating temperature if bed pressure is increased as bed temperature increases. 25

\section{Sorbent regeneration in pressurized FBC systems}

Both Exxon and ANL have been able to regenerate lime and recirculate it for three to five cycles or more.71,72 In both cases, the lime is sulfatcd not uure than 50\% prior to recycling. The Exxon proccss for regenerating the lime and extracting elemental sulfur reruires about $8 \%$ of the energy available in the coal fed to the fluidized bed, whereas the ANL process (designed to accomplish the same purpose) gives promise of requiring only $2 \%$ of the energy in the coal. Representatives of both laboratories have emphasized that the ash decrepitates rapidly so that at no time does the amount of ash in the bed exceed $20 \%$ and it is often as little as $10 \%$ under equilibrium conditions.

Tests of various sorbents at Exxon indicate that the most promising is harium titanate, $\mathrm{BaTHO}_{3}$. This material appears to be twice as effective for absorbing sulfur dioxide as calcium oxide. It is very resistant to attrition, so that Exxon believes that as much as 100 recycles with the $\mathrm{BaTiO}_{3}$ can be achieved as opposed to aruund 5 for $\mathrm{CaO}$. However, the $\mathrm{BaTiO}_{3}$ is more expensive.

$$
\text { No Emissions }
$$

Although the bed operating temperature is low enough so that one would not expect an appreciable percentage of oxides of nitrogen in the emiscions, appruclable amounts are found, apparently as a consequence of nitrogenous compounds present in the coal. Thus, although the NO ${ }_{x}$ concentration in the stack gas from a fluidized-bed coal combustion system commonly runs several times the level expected for the bed operating temperature if no nitrogenous compounds were present in the coal, it is only about half the EPA 1imits. 53 


\section{Coal Metering and Feed Equipment}

A wide variety of coal metering and feed equipment has been employed in experiments but none has proved completely satisfactory. In all cases it has been found that for consistent coal metering and feed, the crushed coal must be dried to less than $1 \%$ superficial moisture or else the coal feed rate becomes erratic and sometimes plugging or clogging of elements of the system occurs. ${ }^{73}$ The latter has proved to be a particularly troublesome problem in tests to date of the Rivesville plant, so much so that relatively little operating time has been obtained.27,74 Note that the Rivesville plant is deliberately being operated with no drying of the coal feed. Note, also, that in the past where coal has been transported pneumatically as for pulverized coal burners for central stations or even in the old Iron Fireman household stokers, the coal fecd stream has always been dried before it was metered and fed to the combustion chamber.

Feeding the coal pneumatically at a pressure above atmospheric introduces the need for some kind of a seal in the coal feed system. ${ }^{75}$ This can be accomplished with lock hoppers (which are used at BCURA, Exxon, and Argonne) or with a device such as a rotary valve. There is extensive operating experience with both types of equipment in the chemical process industry but neither has been fully satisfactory. Rotary valves have been particularly subject to difficulty with wear, a condition that can be eased by designing the system so that the pockets in the rotary valve do not operate full (an approach which increases the life of the valve from a few days to many months).

Rotary valves can be used for metering, but if this approach is followed, the valve pockets must be full and the life of the valve is very short if there is a significant pressure differential across it. Screw feeders have given good service and will operate satisfactorily against a small back pressure. They have the advantage that there is a linear relation between the feed rate of the solid and the rotational speed of the screw. It might be noted that in a full-scale bench test at ORNL a rotary valve running only partially full was used to bring dry crushed coal from an atmospheric pressure bin into a pressurized pneumatic ronal feed system, and a screw feeder was employed to accomplish the 
metering. A bench test for this system was conducted for $1000 \mathrm{hr}$ with uniformly consistent metering. 73

One problem in a coal feed and metering system is splitting the coal feed stream into a multiplicity of flows to different coal feed ports. One way of accomplishing this is to employ a vibrating table with a feed at the inlet end and splitter vanes to separate the flow into a multiplicity of outlet streams. This type of machine has the disadvantage that while it can be adjusted to maintain a particular coal feed rate with reasonably consistent splitting of the stream into a multiplicity of substreams, it appears to work well only for a rather narrow range of feed rates; a poor outlet distribution develops if the coal feed rate is varied over a wide range. Better results may be obtained by using a serles of ore sample dividers; tests with these gave consistent splitting of a coal feed stream into four substreams with less than $\pm 5 \%$ variation from the mean for flow rates from 25 to $100 \%$ of the design value. ${ }^{73}$

Another approach is to feed a single stream into a block with radial outlet ports (four or more). Large units which require splitting the feed stream to dozens of separate feed nozzles will require careful development and testing to assure adequate feed distribution.

\section{Fireside Corrosion}

As indicated earlier in this report, fireside corrosion problems are sufficiently complex and dependent on many different variables that a truly comprehensive program will be required to provide a firm basis for the design of fluidized-bed coal combustion systems. ${ }^{76,77}$ Some notion of the amount of testing required is given by the fact that there are about 10 key independent parameters and it would be desirable to vary each of these over an appreciable range - say at least three different conditions. Even assuming that one can select the nearly optimum value for each of these 10 parameters in advance and run a base case for reference purposes, it would then be necessary to run an additional 20 cases varying each one of the parameters either to the high or the low side of the optimum just to get an idea of the importance of each parameter. In addition, it 
would be highly desirable to see whether there are synergistic effects of varying two parameters simultaneously, but this would entail hundreds of additional tests. The cost of such a program and the time required to carry it out is rendered still more formidable by the fact that each test must be run at least 3000 to $5000 \mathrm{hr}$ to obtain a significant indication of a satisfactorily long life. Thus, it is clear that a judicious selection of test conditions must be made to keep the fireside corrosion test program within manageable limits. Table 6 indicates what such a program might include. The results of the corrosion tests run to date are also summarized in Table 6.51-55 If these data are compared with the range of conditions of interest, th is clear that much additional experimental work must be carried out before designers will have a firm basis for the design of full-scale fluidized-bed furnaces.

\section{Fast Fluidized Beds}

A number of concepts for fluidized-bed coal combustion systems envision operation with superficial velocities sufficiently high that the solid particles in the bed are entrained and circulate around a loop. 27 One such concept under Investigation by the Battelle Memorial Institute (BMI) makes use of a bed of $\mathrm{Fe}_{2} \mathrm{O}_{3}$ particles that are -8 mesh in size.78,79 Streams of -325 mesh calcium oxide particles and $-1 / 4-i n$. coal are injected into this bed. In addition, -20 mesh $\mathrm{SiO}_{2}$ particles recirculated through the bed. With this arrangement a 27-to-1 ratio of $\mathrm{CaO}$ to carbon ls ublained in the circulating fluid with the iron oxide particles remaining just above the air distributor plate while the fines circulate rapidly through the iron oxide bed and then upward through the combustion space. The iron oxide bed has a settled height of 15 to 19 in. and an expanded height of $40 \mathrm{in.}$ in operation. The first-stage cyclone takes out the silica and calcia for circulation through a steam generator and back into the bed. The fines from attrition of the other materials together with the ash are carried into the second-stage separator, where the bulk of them are removed. The attrition rate on the iron oxide particles leads to a makeup requirement of $0.31 \mathrm{~b} \mathrm{Fe}{ }_{2} \mathrm{O}_{3}$ per $100 \mathrm{lb}$ of coal, and the attrition of the $\mathrm{SiO}_{2}$ is $\sim_{2} 1 \mathrm{~b}$ per $100 \mathrm{lb}$ of coal. The ratio of calcia feed to the sulfur in the coal is approximately 2 for $88 \%$ sulfur 
Table 6. Controlled experiments in the systematic investigation of alloy corrosion in fluidized-bed coal combustion systems

\begin{tabular}{|c|c|c|c|c|c|}
\hline \multirow[b]{2}{*}{ Parameter } & \multirow[b]{2}{*}{ Range of interest } & \multicolumn{4}{|c|}{ Controllet experiments } \\
\hline & & BCURA & $\begin{array}{l}\text { Combustion } \\
\text { Power }\end{array}$ & $\begin{array}{l}\text { EPRI- } \\
\text { Stoke } \\
\text { Orchard }\end{array}$ & ORNL-FluiDyne \\
\hline Bed size, $i t^{2}$ & $13,10,>35$ & 6.25 & 2.2 & 1.0 & 2.25 \\
\hline Furnace press., atm & $=, 3,10$ & & 1 & 1 & 1 \\
\hline Bed temperature, ${ }^{\circ} \mathrm{F}$ & $1506,1625,1750$ & 1560 & $1600,-? 00$ & & 1635 \\
\hline Type of coal & $\begin{array}{l}\text { Bitumincus, sub- } \\
\text { b-tumirous, lignite }\end{array}$ & Pittsburgh & Illinois Yo. 6 & I1I. No. 6 I & Illinois No. 6 \\
\hline Volatiles, $\%$ & $0-40$ & & 33.4 & & \\
\hline Sulfur content, $\%$ & $1,3,5$ & & $3.2:$ & & \\
\hline Ash content, $\%$ & $5,10,20$ & & 13.1 & & \\
\hline Particle size & $-1 / 4$ in., $-8,-16$ & . & $<1 / 4,<1 / 8$ in. & & \\
\hline Type of sorbent & $\begin{array}{l}\text { Limestones } \& \text { dolomites } \\
\text { of different porosity, } \\
\text { clay adjitives }\end{array}$ & & $\begin{array}{l}\text { Dolomite with } \& \\
\text { without clay }\end{array}$ & $\mathrm{L}$-mestone & Limes tone \\
\hline $\begin{array}{l}\text { Superficial velocity, } \\
\mathrm{ft} / \mathrm{sec}\end{array}$ & $2,4,8$ & 2.2 to 2.5 & & 3 & 2.3 \\
\hline Excess air, \% & $5,10: 20$ & 14 to 20 & $r_{v} 200$ & 15 & 10 \\
\hline Calcium-sulfur ratio & 1.5 to 4 & 1.4 to 2.2 & 1.37 & 2 & $5^{a}$ \\
\hline Alloy & wlo tspes & 7 Elloys & 22 alloys & 20 & 5 alloys \\
\hline Coating & None, 2 types & None & None & None & Alonized \\
\hline Alloy temperature, ${ }^{\circ} \mathrm{F}$ & $\begin{array}{r}700,-200,1500 \\
\text { bed iemperature }\end{array}$ & $\begin{array}{l}700,920,1100 \\
1316,1560\end{array}$ & 1600 & $\begin{array}{r}1000,1200 \\
1400,1500\end{array}$ & $1530-1610$ \\
\hline Alloy location & In bed \& in Ireeboard & Io bed \& in freeboard & Freeboard & Bed \& freeboard & In bed \\
\hline $\begin{array}{l}\text { Running time per } \\
\text { test, hr }\end{array}$ & $500,1000,3000$ & 500 & 100,1000 & 1000 & 1500 \\
\hline
\end{tabular}

${ }^{\mathrm{a}} \mathrm{SO}_{2}$ enission level of $150 \mathrm{ppn}$. 
retention when burning $4 \%$ sulfur coal. The NO ${ }_{x}$ concentration in the flue gas runs $\sim 350 \mathrm{ppm}$. There are no tubes in the bed, but 2-in.-diam tubes have been installed above the bed for measurement of heat transfer co-efficients in the entrained bed flowing up out of the bed of iron oxide particles. These experiments have shown severe erosion of horizontal surfaces but acceptable erosion rates on vertical surfaces. The heat transfer coefficient in the tube bundle has run approximately $25 \mathrm{Btu} / \mathrm{hr}-$ $\mathrm{ft}^{2}-{ }^{\circ} \mathrm{F}$. Approximately $15 \%$ of the carbon goes through the bed and furnace unburned and most of it is taken out in the second-stage cyclone; some of it, of course, recirculates with the calcia and silica. Of the conbustion that does take place, $83 \%$ occurs in the iron oxide bed and only $17 \%$ in the entrained bed in a $30-$ to $40-\mathrm{ft}$ plenum above the iron oxide fluidized bed. Note that all these values are based on about $300 \mathrm{hr}$ of testing at Battelle with a 6-in.-diam bed. Unless transverse mixing is very good, the performance of large-diameter beds may be substantially less favorable. Note, too, that the pumping power requirement is inherently high for fast fluidized beds.

\section{REFERENCES}

1. A. P. Fraas, Comparison of Advanced Energy Conversion Systems on the Basis of R\&D Experience, ORNL-TM-6259 (to be published).

2. The Babcock \& Wilcox Company, Steam: Its Generation and Use, 37th ed., New York, 1955.

3. H. B. Reynolds et al., "New Boiler Equipment at the Interborough Rapid Transit Co.'s Fifty-Ninth Street Power Station," Trans. ASME, 4 8 , 1369 (1926).

4. A. M. Greene, Jr., "The Tale of Two City Stations: A Half Century of Progress in Steam-Power Generation," Mech. Eng., 63, 109 (1941).

5. E. E. Keller and F. Hodgkinson, "The Steam Turbine in the United States: I-Developments by the Westinghouse Mach1ne Company," Mcch. Eng., 58, 683 (1936).

6. A. G. Christie, "The Steam Turbine in the United States: II Early Allis-Chalmers Steam Turbines," Mech. Eng., 59, 71 (1937).

7. E. L. Robinson, "The Steam Turbine in the United States: IIIDevelopments by the General Electric Company," Mech. Eng., 59, 239 (1937). 
8. D. S. Kimball, "The Century's Great Inventions," Mech. Eng., 59, 507 (1937).

9. W. E. Blowney and G. B. Warren, "The Increase in Thermal Efficiency Due to Resuperheating in Steam Turbines," Trans. ASME, 46, 563 (1924).

10. A. G. Christie, "Development and Performance of American Power Plants," Mech. Eng., 58, 539 (1936).

11. H. J. Kerr, "Once-Through Series Boiler for 1500 to $5000 \mathrm{Lb}$. Pressure," Trans. ASME, 54, RP-54-1a (1932).

12. Jacques Gastpar, "European Practice with Sulzer Monotube Steam Generators," Trans. A.ME, 75, 1345 (195J).

13. W. H. Rowland and A. M. Frendberg, "First Commercial SupercriticalPressure Steam Generator for Philo Plant," Trans. ASME, /Y, 109 $(1957)$.

14. C. A. Dauber, "Avon No. 8-A Supercritical-Pressure Plant," Trans. ASME, 79, 727 (1957).

15. C. B. Campbell, C. C. Franck, Sr., and J. C. Spahr, "The Eddystone Super-pressure Unit," Trans. ASME, 79, 1431 (1957).

16. R. W. Wolfe, "Energy Conversion Alternatives Study (ECAS), Westinghouse Phase I Final Report, Volume XI-Advanced Steam Systems," NASA CR-134941 (Fehruary 12, 1976).

17. J. E. Dolan, "American Electric Power's 1300 MW Coal-Fired Series," Proceedings of the American Power Conference, 37, 147 (1975).

18. C. W. Elston, "Design and Development Philosophy to Achieve High Reliability and Long Life in Large Turbine Generators," Paper No. AAS73055, presented to the American Astronautical Society (September 1976).

19. C. M. Davis et a1., "Large Utility Bollers - Experience and Dusign Trendo," l'roceedings of the American Power Conference, 38, 280 (1976).

20. W. G. Henke, "The New 'Hot' Electrostatic Precipitation," Combustion (October 1970).

21. C. L. Bazelmans et al., study of Options for Control of Emissions from an Existing Coal-Fired Electric Power Station, ORNL-TM-4298 (September 1973).

22. J. K. Burchard et al., "Some General Fconomic Consideralions of F'lue Gas Scrubbing for Utilities," Proceedings of Conference on Sulfur in Utility Fuels: The Growing Dilemma, Drake Hotel, Chicago, October 25-26, 1972.

23. H. F. Hartman et a1., Low Btu Coal Gasification Study, ORNL-TM(to be published). 
24. "Multi-Stream Coal Cleaning System Promises Help with Sulfur Problem," Coal Age, 81, 86-88 (January 1976).

25. D. Anson, "Fluidized Bed Combustion of Coal for Power Generation," Prog. Energy Combust. Sci., 2, 61-82 (1976)

26. A. M. Squires, "Applications of Fluidized Beds in Coal Technology," Chap. 4, p. 49 of Alternative Energy Sources, Academic Press, New York (1976).

27. T. E. Stringfellow and J. G. Branam, "Start-up and Initial Operation of the Rivesville 30 MW Fluid Bed Boiler," Proceedings of the 5th International Conference on Fluidized Bed Combustion, Washington, D.C., December 12-14, 1977.

28. D. F. Spencer, O. D. Guildersleeve, and R. A. Loth, "Initial Comparative Analysis of the Market Penetration Potential of Coal and Coal Derived Fuels in the United States Utility Industry (1985-2005)," presented at the IEEE PES Summer Meeting, Mexico City, Mexico, July $17-22,1977$.

29. D. H. Brown et al., Energy Conversion Alternatives Study (ECAS), General Electric Phase II Final Report, Vo.1. II, Advanced Energy Conversion Systems - Conceptual Designs, Part 2, Closed Cycles, NASA-CR 134949, SRD-76-064-2 (December 1976).

30. T. W. Berker, "Application of Atmospheric Fluidized Bed Combustion for Electric Power Generation," Proceedings of the 5th International Conference on Fluidized Bed Combustion, Washington, D.C., December $12-14,1977$.

31. R. B. Core1.1., "Conceptual Design of a 570 MW Combustion Engineering, Inc. Atmospheric Fluidized Bed Steam Generator," Proceedings of the 5 th International Conference on Fluidized Bed Combustion, Washington, D.C. December 12-14, 1977.

32. K, A. Reed and R. L. Gamble, "Conceptual Design of a 570 MW FosterWheeler Energy Corp. Atmospheric Fluidized Bed Steam Generator," Proceedings of the 5th International Conference on Fluidized Bed Combustion, Washington, D.C., December 12-14, 1977.

33. A. P. Fraas, G. Samuels, and M. E. Lackey, "A New Approach to Fluidized Bed Steam Boiler," ASME Paper No. 76-WA/Pwr-8 (December 1976).

34. M. Fartlier, " $\Lambda$ pplication of Fluidized Bed Combustion Technology to Industrial Boilers," paper presented at the Filuidized Bed Combustion Technology Exchange Workshop, McLean, Virginia, April 13-15, 1977.

35. R. Webb, "Natural Versus Forced Circulation in Fluidized Bed Combustion," paper presented at the Fluidized Bed Combustion Technology Exchange Workshop, McLean, Virginia, April 13-15, 1977. 
36. W. Miller, "Fluidized Bed Boiler at Georgetown University," paper presented at the Fluidized Bed Combustion Technology Exchange Workshop, McLean, Virginia, April 13-15, 1977.

37. A. P. Fraas, "Survey of Turbine Bucket Erosion, Deposits, and Corrosion," ASME Paper No. 75-GT-123 (December 1964).

38. M. E. Lackey, Summary of the R\&D Effort on Direct Coal-Fired Gas Turbines, ORNT.-TM-6253.

39. W. R. Barclay, "Contributions of Metallurgy to Engineering Progress," Mech. Eng., 60, 595 (1938).

40. A. P. Fraas, "Heat Exchangers for High Temperature Thermodynamic Cycles," ASME Paper No. 75-WA/HT-102 (December 1975).

41. S. Y. Lee et al:, "Laboratory Procedures for Fvaluating lligli= Tempcrature Corrósinn Resictance of Cas Turbine Alloys," Trans. ASME, 93, 313 (1971).

42. W. Nelson and C. Cain, Jr., "Corrosion of Superheaters and Reheaters of Pulverized-Coal-Fired Boilers," Trans. ASME, 82, 194 (1960).

43. H. A. Blank et al., "Behavior of Superheater Tubing Materiais in Contact with Combustion Atmospheres at $1950^{\circ} \mathrm{F}, "$ Trans. ASME, 74, 813 (1952).

44. V. J. Calise and J. H. Muff, "Treatmenl of Make-Up Feedwater, Condensate, and Recycle Water for Supercritical and Nuclear-Reactor Power-Plant Cycles," Trans. ASME, 80, 1659 (1958).

45, G. A. Hawkius et al., "The Corrosion of Alloy Steels by HighTemperature Steam," Trans. ASME, 66, 291-295, (1944).

46. M. C. Bloom et al., "Corrosion Studies in High Temperature Water by a Hydrogen Effusion Method," Corrosion, 13, 297t-302t (May 1957).

17. R. Scliuster, "Directions in Peaking," Power Engineering (October 1972).

48. B. Wood, "Wetness in Steam Cycles," Proceedings of the Institution of Mechanical Engineers, 174(14), 491-511 (1960).

49. A. P. Fraas et a1., Survey of Information on Turbine Bucket Erosion, ORNL-TM-2088 (July 1968).

50. R. A. Woud, Status of Titanium Blading for Low Pressure Steam Turbines, EPRI AF-445 (February 1977).

51. S. Ehrlich and J. Stringer, "High Temperature Corrosion in Fluidized Bed Combustors," ASME 76-WA/CD-4 (December 5, 1976). 
52. J. Stringer, "High Temperature Corrosion of Metals and Alloys in Fluidized Bed Combustion Systems," Proceedings of the 5th International Conference on Fluidized Bed Combustion, Washington, D.C., December 12-14, 1977.

53. British Coal Utilization Research Association R\&D Report No. 85 to Office of Coal Research. (September 1973).

54. "Hot Corrosion in the Direct-Coal-Fired Turbine," Energy Research and Development Administration No. E(49-18)-1536 (September 1976).

55. R. H. Cooper, Preliminary Report on Corrosion Analysis of Heat Exchanger Tubes from a Fluidized-Bed Coal Combustor, ORNL-TM- (to be published).

56. E. L. Daman, "Design and Application of Supercharged Boilers," paper presented at Philadelphia Section of Society of Naval Architects and Marine Engineers, April 15, 1955.

57. W. A. Fritz, Jr. and T. P. Tursi, Jr., "Development and Experience with a Supercharged Steam-Generating System," Marine Technology (January 1967).

58. A. Meyer, "The Velox Steam Generator, Its Possibilities as Applied to Land and Sea," Mechanical Engineering, 57, 469-478 (August 1935).

59. M. E. Lackey and A. S. Thompson, Summary of the Development of Open Cycle Gas Turbine-Steam Combined Cycles, ORNL-TM-6252 (to be published).

60. E. L. Bulkley, "New Studies Shed Light on Erosion Problems," Petro/ Chem Engineer, 218 (March 1962).

61. The Coal-Burning Gas Turbine Project, Report of the Interdepartmental Steering Committee, Department of Minerals and Energy, Department of Supply, Commonwealth of Australia, 1973.

62. J. Smith et a1., "Bureau of Mines Progress in Developing Open and Closed-Cycle Coal-Burning Gas Turbine Power Plants," Journal of Engineering for Power, $\underline{88}(A-4), 313$ (October 1966).

63. J. G. Wilson and J. C. Dygert, "Separator and Turbo-Expander for Erosive Environments," IP No. 45 P-1533, Shell Development Company, presented at the 7 th World Petroleum Conference, Mexico City, April 1967 .

64. J. P. Balfoort, "Improved Hot-Gas Expanders for Cat Cracker Flue Gas," Hydrocarbon Processing (March 1976).

65. A. Strub, "Field Experience with Industrial Gas Turbine Installation," Sulzei Technieal Rcvicw, /8(3), 129 (196fi). 
66. M. S. Nutkis et al., "Evaluation of a Granular Bed Filter for Particulate Control in Fluidized Bed Combustion," Proceedings of the 5th International Conference on Fluidized Bed Combustion, Washington, D.C., December 12-14, 1977.

67. J. L. Guillory, "Filtration Performance of a Moving Bed Granular. Filter: Experimental Cold Flow Data," Proceedings of the 5th International Conference on Fluidized Bed Combustion, Washington, D.C., December 12-14, 1977.

68. S. Moskowitz, "The Curtiss-Wright Pressurized Fluidized Bed Pilot Electric Plant," Proceedings of the 5th International Conference on Fluidized Bed Combustion, Washington, D.C., December 12-1.4, 1.977.

69. E. A. Farber and R. L. Scorah, "Heat Transfer to Water Boiling Under Pressure," ASME Transactions, 70, 369 (1948).

70. "Evaluation of the Fluidired Bed Combustion Frocess," Vo1. I Summary Report, Westinghouse Research Laboratories, Pittsburgh, Pennsylvania (1972).

71. L. A. Ruth et al., "Pressurized Fluidized Bed Combustion and Sorbent Regeneration," Proceedings of the 5th International Conference on Fluidized Bed Combustion, Washington, D.C., December 12-14, 1977.

72. A. Jonke, G. Vogel, and I. Johnson, "Sulfated Limestone Regeneration and General FBC Support Studies," paper presented at the Fluidized Bed Combustion Technology Exchange Workshop, McLean, Virginia, Apri1 13-15, 1977.

73. M. E. Lackey, Design and Performance Testing of a Coal Feed and Metering System for the MIUS Fluidized Bed Combustor, ORNL/HUD/MLIIS47 (December 1977).

74. J. Mesko, "Light-Off and Initial Operation of the 30 MWe Rivesville Multi-Cell Fluidized Bed Boiler," paper presented at the Fluidized Bed Combustion Technology Exchange Workshop, McLean, Virg1nia, Apri1 $13-15,1977$.

75. Proceedings of the Conference on Coal Feeding Systems, prepared by California Institute of Technology for FRnA, June 21-23, 1977.

76. M. Nuck1s, "A Program for Hot Corrosion/Erosion Materials Testing for Applications to Fluidized Bed Coal Combustion," paper presented at the Fluidized Bed Combustion Technology Exchange Workshop, McLean, Virginia, April 13-15, 1977.

77. S. Van Grouw, "Corrosion Studies and High Temperature Filtration," paper presented at the Fluidized Bed Combustion Technology Exchange Workshop, McLean, Virginia, April 13-15, 1977. 
78. H. Nack, "Battelle's Multi-Solids Fluidized Bed Combustion Process for Industrial Boiler Applications," paper presented at the Fluidized Bed Combustion Technology Exchange Workshop, McLean, Virginia, Apri1 13-15, 1977.

79. H. Nack et al., "Battelle's Multisolid Fluidized Bed Combustion Process," Proceedings of the 5th International Conference on Fluidized Bed Combustion, Washington, D.C., December 12-14, 1977. 
THIS PAGE

\section{WAS INTENTIONALLY LEFT BLANK}


ORNL/TM-6250

Dist. Category UC-90f

\section{Internal Distribution}

$\begin{aligned} \text { 1. } & \text { D. M. E1ssenberg } \\ 2 . & \text { E. C. Fox } \\ \text { 3-7. } & \text { A. P. Fraas (Consultant) } \\ 8 . & \text { T. G. Godfrey } \\ 9 . & \text { R. L. Graves } \\ 10 . & \text { W. L. Greenstreet } \\ 11 . & \text { E. C. Hise } \\ 12 . & \text { R. S. Holcomb } \\ 13-15 . & \text { J. E. Jones Jr. } \\ 16 . & \text { M. E. Lackey } \\ 17 . & \text { R. E. MacPherson } \\ \text { 18-22. } & \text { L. E. McNeese } \\ 23 . & \text { W. R. Mixon } \\ 24 . & \text { T. W. Picke1 } \\ 25 . & \text { M. L. Poutsma }\end{aligned}$

26. T. W. Robinson, Jr.

27. M. W. Rosenthal

28. T. H. Row

29. G. Samuels

30. C. D. Scott

31. I. Spiewak

32. A. S. Thompson (Consultant)

33. H. E. Tramme11

34. D. B. Trauger

35. G. P. Zimmerman

36. ORNL Patent Office

37. Central Research Library

38. Document Reference Section

39-40. Laboratory Records Department

41. Laboratory Records, RC

\section{External Distribution}

42. S. Alpert, EPRI, 3412 Hillview Ave., Palo Alto, Calif. 94304

43. D. H. Archer, Westinghouse Research Laboratory, 1310 Beulah Road, Pittsburgh, Pa. 15235

44. J. T. Bartis, Office of Plans \& Technology Assessment, DOE, Fossil Energy, MS C-164, Germantown, Washington, D.C. 20545

45. D. H. Broadhent, National Coal Board (IEA Services Ltd.), 14/15 Lower Grosvenor Place, London, England

46. R. D. Brooks, General Electric Co., Energy Systems and Technology Division, Bldg. 2, Schenectady, N.Y. 12345

47. Robert Brookshire, Tennessee Valley Authority, 1360 Commerce Union Bank B1dg., Chattanooga, Tenn. 37401

48. John Byam, Morgantown Energy Technology Center, P.0. Box 880, Morgantown, W.Va. 26505

49. N. H. Coates, The Mitre Corp., Westgate Research Park, McLean, Va. 22101

50. A. Cohn, EPRI, 3412 Hillview Ave., Palo Alto, Calif. 94304

51. H. G. Corneil, Exxon Enterprises, Inc., 1251 Avenue of the Americas, New York, N.Y. 10020

52. Russel1 Covell, Combustion Engineering, Inc., 1000 Prospect Hill Koad, Windsor, Conn. 06095

53. W. M. Crim, Office of Coal Utilization Systems, DOE, Fossil Energy, Mail Code E-178, Germantown, Washington, D.C. 20545

54. E. L. Daman, Foster Wheeler Corp., 110 S. Orange Ave., Livingston, N.J. 07039

55. C. W. Di Bella, Department of Energy, Oak Ridge Operations, P:o. Box E, Oak Ridge, Tenn. 37830 
56. Shelton Ehrlich, EPRI, 3412 Hillview Ave., P.0. Box 10412, Palo Alto, Calif. 94304

57. C. W. Elston, General Electric Co., Bldg. 273, 1 River Road, Schenectady, N.Y. 12345

58. John Eustis, Office of Industrial Programs, DOE, 1000 Independence Ave., Washington, D.C. 20545

59. H. L. Falkenberry, Coal Research Management, DOE, 1200 Pennsylvania Ave., N.W., Mail Code 3344, Washington, D.C. 20461

60. E. C. Feher, TRW, Mail Station 01/2270, 1 Space Park, Redondo Beach, Calif. 90278

61. T. J. Fitzgerald, Oregon State University, Chemical Engineering Department, Corvallis, Ore. 97331

62. R. W. Foster-Pegg, Westinghouse Electric Corp., Gas Turbine Engine Division, P.O. Box 251, Concordville, Penn. 19331

63. Steven Freedman, Office of Co2l Utilization Eystems, Fossil Energy, DOE, Mail Code E-178, Germantown, Washington, D.C. 20545

6\%. J. A. Fullam, Ingersol1-Rand Co., Process Compressor and Expanders, Turbo Products Division, Phillipsburg, N.J. 08865

65. F. D. Gmeind1, Morgantown Energy Technology Center, P.0. Box 880, Morgantown, W.Va. 26505

66. G. H. Goff, Research and Engineering, Bechtel Corp., 50 Beale St., San Francisco, Calif. 94119

67. Jerry Golden, Tennessee Valley Authority, Knoxville Office Complex, 400 Commerce Avenue, W10A19, Knoxville, Tenn. 37902

68. W. B. Harrison, Southern Company Services, Inc., P.0. Box 2625, Birmingham, Ala. 35202

69. H. R. Hazard, Battelle Columbus Laboratories, 505 King Avenue, Coluinbus Uhio 43201

70. T. A. Hetrick, Elliott Company, Jeannette, Pa. 15644

71. R. C. Hoke, Exxon Research and Engineering Co., P.0. Box 8, Linden, N.J. 07035

72. J. J. Horgan. United Terhnn1ngies Corporation, P.0. Box 109, Buullı Windsor, Conn. 06109

73. H. R. Hoy, Director, Leatherhead Laboratory, National Coal Board (BCURA, Ltd.), Randalls Road, Leatherhead, Surrey, England

74. Robert Jaffee, EPRI, 3412 Hillview Ave., Palo Alto, Calif. 94304

75. D. L. Keairns, Westinghouse Electric Curp., 1310 Beulah Road, B1dg. 501, Pittsburgh, Pa. 15235

76. Carey Kinney, Olfice of Coal Utilization Systems, Fossil Energy, DOE, Mail Code E-178, Germantown, Washington, D.C. 20545

77. C. W. Knudson, General Electric Co., Energy Systems and Technology Division, Bldg. 2, Sehenectady, N.Y. 12345

78. L. R. Lawrence, Jr., Gas Research Institute, 3424 S. State St., Chicago, I11. 60616

79. E. K. Levy, Lehigh University, B1dg. 9, Bethlehem, Pa. 18015

80. R. A. Loth, EPRI, 3412 Hillview Ave., Palo Alto, Calif. 94304

81. J. F. Louis, Massachusetts Institute of Technology, 77 Massachusetts Ave., Energy Laboratory, Room 31-254, Cambridge, Mass. 02139

82. T. E. Lund, EPRI, 3412 Hillview Ave., P.0. Box 10412, Palo Alto, Calif. 94304

83. J. J. Markowsky, American Electric Power, 2 Broadway, New York, N.Y. 10004 
84. C. H. Marston, General Electric Company, 1 River Road, Schenectady, N.Y. 12345

85. M. J. Mayfield, Tennessee Valley Authority, 1020 Chestnut Street Tower-II, Chattanooga, Tenn. 37401

86. C. F. McDonald, General Atomic Co., P.0. Box 81608, San Diego, Calif. 92138

87. J. L. Morgan, General Electric Co., 1 River Road, Schenectady, N.Y. 12345

88. Seymour Moskowitz, Curtiss-Wright Corp., One Passaic Street, Wood-Ridge, N.J. 07075

89. Abolhassan Nazemi, The Mitre Corp./METREK Division, Westgate Research Park, McLean, Va. 22101

90. W. T. Newberry, Tennessee Valley Authority, 1020 Chestnut Street Tower-II, Chattanooga, Tenn. 37401

91. M. B. Neuworth, Mitre, 1820 Dolley Madison Blvd., McLean, Va. 22101

92. Kent Philips, Combustion Power Company, Inc., Memlo Park, Calif. 94025

93. Jim Powell, Brookhaven National Laboratory, Department of Applied Science, Upton, N.Y. 11973

94. Lynn Rubow, Gilbert Associates, P.0. Box 1498, Reading, Pa. 19603

95. J. Shang, The Mitre Corp., Westgate Research Park, McLean, Va. 22101 ,

96. L. I. Shure, NASA-Lewis Research Center, 21000 Brookpark Road, Cleveland, Ohio 44135

97. Lyle Six, AiResearch Mfg. Co., 402 South 36th Street, Phoenix, Ariz. 85034

98. J. W. Smith, Babcock and Wilcox, 20 South Van Buren Avenue, Barberton, Ohio 44203

99. E. V. Somers, Westinghouse Electric Corp., Research and Development Center, Churchill Boro, Pittsburgh, Pa. 15235

100. A. M. Squires, Department of Chemical Engineering, Virginia Polytechnic Institute, Blacksburg, Va.

101. Beno Sternlicht, Mechanical Technology, Inc., 968 Albany Shaker Road, Latham, N.Y. 1.2110

102. R. H. Tourin, Program Director, New York State ERDA, 230 Park Avenue, New York, N.Y. 10017

103. J. G. Vlahakis, Coal Liquefaction Division, Industrial \& Utility Applications and Operations, DOE, Federal Building, 1200

Pennslyvania Ave., Washington, D.C. 20461

104. G. E. Voelker, Office of Coal Utilization Systems, Fossil Energy, DOE, Mail Code E-178, Germantown, Washington, D.C. 20545

105. A. M. Weinberg, Institute for Energy Analysis, ORAU, P.O. Box 117, Oak Ridge, Tenn. 37830

1.06. J. F. Weinhold, Tennessee Valley Authority, 1345 Commerce Union Bank Bldg., Chattanooga, Tenn. 37401

107. G. C. Weth, Office of Coal Utilization Systems, Fossil Energy, DOE Mai.l Code E-178, Germantown, Washington, D.C. 20545

108. D. M. Willyoung, General Electric Co., 1 River Road, Schenectady, N.Y. 12345

109. H. W. Withers, Tennessee Valley Authority, 1020 Chestnut Street lower-II, Chattannoga, Tenn, 37401 
110. F. A. Zenz, F. A. Zenz, Inc., P.O. Box 205, Garrison, N.Y. 10524

111. W. Zimmerman, General Electric Co., Advanced Energy Program, Evendale, Ohio 45215

112. Office of Assistant Manager for Energy Research and Development, DOE, Oak Ridge Operations Office, Oak Ridge, Tenn. 37830

113-338. Given distribution as shown in DOE/TIC-4500 under category UC-90f 